\title{
Liquid export of Arctic freshwater components through the Fram Strait 1998-2011
}

\author{
B. Rabe ${ }^{1}$, P. A. Dodd ${ }^{2}$, E. Hansen ${ }^{2}$, E. Falck ${ }^{3}$, U. Schauer ${ }^{1}$, A. Mackensen ${ }^{1}$, A. Beszczynska-Möller ${ }^{1}$, G. Kattner ${ }^{1}$, \\ E. J. Rohling ${ }^{4}$, and K. Cox ${ }^{4}$ \\ ${ }^{1}$ Alfred Wegener Institute for Polar and Marine Research, Bremerhaven, Germany \\ ${ }^{2}$ Norwegian Polar Institute, Troms $\varnothing$, Norway \\ ${ }^{3}$ The University Centre in Svalbard, Longyearbyen, Norway \\ ${ }^{4}$ National Oceanography Centre, Southampton, UK
}

Correspondence to: B. Rabe (benjamin.rabe@awi.de)

Received: 23 July 2012 - Published in Ocean Sci. Discuss.: 14 August 2012

Revised: 22 December 2012 - Accepted: 10 January 2013 - Published: 30 January 2013

\begin{abstract}
We estimated the magnitude and composition of southward liquid freshwater transports in the East Greenland Current near $79^{\circ} \mathrm{N}$ in the Western Fram Strait between 1998 and 2011. Previous studies have found this region to be an important pathway for liquid freshwater export from the Arctic Ocean to the Nordic Seas and the North Atlantic subpolar gyre.
\end{abstract}

Our transport estimates are based on six hydrographic surveys between June and September and concurrent data from moored current meters. We combined concentrations of liquid freshwater, meteoric water (river water and precipitation), sea ice melt and brine from sea ice formation, and Pacific Water, presented in Dodd et al. (2012), with volume transport estimates from an inverse model. The average of the monthly snapshots of southward liquid freshwater transports between $10.6^{\circ} \mathrm{W}$ and $4^{\circ} \mathrm{E}$ is $100 \pm 23 \mathrm{mSv}$ $\left(3160 \pm 730 \mathrm{~km}^{3} \mathrm{yr}^{-1}\right)$, relative to a salinity of 34.9 . This liquid freshwater transport consists of about $130 \%$ water from rivers and precipitation (meteoric water), $30 \%$ freshwater from the Pacific, and $-60 \%$ (freshwater deficit) due to a mixture of sea ice melt and brine from sea ice formation.

Pacific Water transports showed the highest variation in time, effectively vanishing in some of the surveys. Comparison of our results to the literature indicates that this was due to atmospherically driven variability in the advection of Pacific Water along different pathways through the Arctic Ocean. Variations in most liquid freshwater component transports appear to have been most strongly influenced by changes in the advection of these water masses to the Fram
Strait. However, the local dynamics represented by the volume transports influenced the liquid freshwater component transports in individual years, in particular those of sea ice melt and brine from sea ice formation.

Our results show a similar ratio of the transports of meteoric water and net sea ice melt as previous studies. However, we observed a significant increase in this ratio between the surveys in 1998 and in 2009. This can be attributed to higher concentrations of sea ice melt in 2009 that may have been due to enhanced advection of freshwater from the Beaufort Gyre to the Fram Strait.

Known trends and variability in the Arctic liquid freshwater inflow from rivers are not likely to have had a significant influence on the variation of liquid freshwater component transports between our surveys. On the other hand, known freshwater inflow variability from the Pacific could have caused some of the variation we observed in the Fram Strait.

The apparent absence of a trend in southward liquid freshwater transports through the Fram Strait and recent evidence of an increase in liquid freshwater storage in the Arctic Ocean raise the question: how fast will the accumulated liquid freshwater be exported from the Arctic Ocean to the deep water formation regions in the North Atlantic and will an increased export occur through the Fram Strait. 


\section{Introduction}

As already observed by Nansen (1890), fresh and cold waters from the upper Arctic Ocean are transported southward by the East Greenland Current (EGC) in the Western Fram Strait, over the continental slope and the Greenland shelf (for abbreviations, see the Glossary in Table 1). The EGC transports liquid freshwater and ice from the Arctic to the Nordic Seas (e.g. Rudels et al., 2005; Latarius and Quadfasel, 2010), the Denmark Strait and the North Atlantic (Sutherland et al., 2009; Cox et al., 2010). Once in the North Atlantic, this freshwater and ice melt have the potential to influence deep convection and the thermohaline overturning (Manabe and Stouffer, 1999; Rennermalm et al., 2007; Talley, 2008) as well as the horizontal circulation in the subpolar gyre (Häkkinen, 1999).

\subsection{Arctic upper ocean and atmosphere variability}

Previous work has shown that the composition of the southward liquid freshwater transport in the EGC is influenced not only by processes in the Western Fram Strait but also by the circulation in the Arctic Ocean (Meredith et al., 2001; Dodd et al., 2009; Rabe et al., 2009; Jahn et al., 2010). The pathways of freshwater in the Arctic Ocean and their arrival in the Fram Strait are related to both the large-scale atmospheric circulation influencing upper ocean currents and hydrography (Proshutinksy and Johnson, 1997; Steele and Boyd, 1998; Zhang et al., 2003; Häkkinen and Proshutinsky, 2004; Dukhovskoy et al., 2006), and regional processes governing the storage and release of liquid freshwater.

On basin scales, liquid freshwater is stored in and released from the Beaufort Gyre in the Southern Canada Basin but is also advected from the Siberian and Bering Sea shelves to the Fram Strait in the Transpolar Drift. A common conceptual model of upper Arctic Ocean variability entails a switch between strong and weak states of the Beaufort Gyre and the Transpolar Drift on near-decadal timescales (see the review by Mauritzen, 2012). However, the influence of the atmospheric circulation on the Arctic ocean at different timescales is still a subject of ongoing research, as there are different patterns from decadal to interannual timescales (Thompson and Wallace, 1998; Zhang et al., 2008). In addition, there is evidence of a strong influence of regional atmospheric variability on regional freshwater release and advection; for example, the shelf-basin exchange at the Siberian continental slope (Bauch et al., 2011a; Jahn et al., 2010) or Ekman Pumping induced by wind stress in the Amerasian Basin (Rabe et al., 2011).

\subsection{Tracers and freshwater in the Arctic Ocean}

Different freshwater components have been identified from measurements of salinity and water sample analysis of certain tracers: to separate Pacific Water, the ratio of nitrate to
Table 1. Glossary.

- EGC: East Greenland Current

- AW: Atlantic Water

- MW: meteoric water (river runoff and precipitation)

- LFW: liquid freshwater (the sum of all components)

- SIM: net sea ice melt (net effect of melting and freezing)

- IFB: net sea ice brine (-SIM)

- PW: Pacific Water

- FSIM: contribution to freshwater by SIM

- FIFB: contribution to freshwater by IFB (-FSIM), i.e. a reduction in freshwater

- FPW: contribution to freshwater by PW

- NAOSIM: North Atlantic-Arctic Ocean Sea Ice Model

- CTD: Conductivity Temperature Depth

- ADCP: Acoustic Doppler Current Profiler

- 1ADCP: lowered Acoustic Doppler Current Profiler

- vmADCP: vessel-mounted Acoustic Doppler Current Profiler

phosphate has been used (Jones et al., 1998; Falck et al., 2005; Yamamoto-Kawai et al., 2006). River water and precipitation (meteoric water) as well as sea ice melt and brine from ice formation have been distinguished by the isotopic composition of oxygen (Østlund and Hut, 1984; Bauch et al., 1995; Melling and Moore, 1995; Macdonald et al., 1995; Yamamoto-Kawai et al., 2005; Lansard et al., 2012). However, away from the source regions, only the net effect of mixing between sea ice melt and brine from ice formation can be detected using this method.

By distinguishing the composition of freshwater we are able to gain insight into the links between Arctic-wide freshwater circulation and regional freshwater variability. This includes the release of river water from the Siberian shelves, and the release of river water and sea ice melt that previously accumulated in the Beaufort Gyre. Regional ice formation processes also have a strong influence on freshwater inventories by the release of subsurface brine maxima (e.g. Bauch et al., 2009, 2011a) from the shelves into the Arctic basins. These brine maxima have been observed to persist within the Transpolar Drift (e.g. Jones et al., 2008a) to ultimately arrive at the Fram Strait.

\subsection{Liquid freshwater components in the Western Fram Strait}

Building on previous work (Bauch et al., 1995; Falck et al., 2005; Jones et al., 2008b), Dodd et al. (2012) estimated the contributions of different water masses to liquid freshwater variability near $79^{\circ} \mathrm{N}$ in the Western Fram Strait between 1998 and 2011. Dodd et al. (2012) extended the work by Meredith et al. (2001), Dodd et al. (2009) and Rabe et al. (2009), adding further years of observations and distinguishing Pacific Water fractions (concentrations) by considering nutrient measurements in addition to $\delta^{18} \mathrm{O}$ and salinity. 
Along the summer sections, inventories of liquid freshwater, meteoric water and net sea ice melt integrated between $10^{\circ} \mathrm{W}$ and the Greenwich Meridian varied by up to $50 \%$ in time. Meteoric water peaked around 2005/2008, related to enhanced levels of meteoric water in the Transpolar Drift following the eastward diversion of meteoric water from the Siberian shelves during the 1990s (Steele and Boyd, 1998). The most Pacific Water was found in 1998 and none in 2004 and 2005. This has been linked to temporary changes in the pathways of Pacific Water (Falck et al., 2005) and the strength of the Beaufort Gyre (Proshutinsky et al., 2009). As fractions of net sea ice melt were largely negative in all sections, this water mass in the outflow from the Arctic was most strongly influenced by brine from ice formation. The net freshwater deficit due to mixing of this brine and sea ice melt decreased between 1998 and 2011; this means that negative values of net sea ice melt increased toward zero. Concurrently, Dodd et al. (2012) observed enhanced levels of positive net sea ice melt near the surface from 2009 onwards. This could be caused by enhanced advection of sea ice melt to the Fram Strait and enhanced mixing with brine from ice formation on the way.

This study aims to quantify the southward transport of liquid freshwater components in the Western Fram Strait for six surveys between 1998 and 2011. We combined a subset of the liquid freshwater component fractions presented in Dodd et al. (2012) with corresponding velocities from an inverse analysis, as described in Sect. 2. This subset represents surveys where shipboard velocity measurements were available, allowing us to estimate transports with an error much reduced from similar estimates using only moored velocity observations (see Rabe et al., 2009, for a comparison). Extending the work of Meredith et al. (2001) and Rabe et al. (2009), we estimated transports not only of liquid freshwater, meteoric water and net sea ice melt, but also of Pacific Water, and we include further surveys available after 2005. Our work is extending that of Dodd et al. (2012) by investigating the combined effect of the occurrence of liquid freshwater components in the Fram Strait as well as the dynamics (velocity) using the water mass transports. On the other hand, we are only able to cover a subset of the surveys presented in Dodd et al. (2012). The results in Sect. 3 show that levels of meteoric water transports peaked in 2005, but reduced to 1998 levels or below thereafter. Significant southward Pacific Water transports were again found in the Western Fram Strait in 2008 and 2011. The results are discussed in the context of other literature in Sect. 4. Our results indicate that changes in the liquid freshwater component transports are linked to Arctic regional processes and large-scale circulation. A summary of this study and concluding remarks are given in Sect. 5 .

\section{Data and methods}

\subsection{Temperature and salinity profiles}

Temperature and salinity from CTD (Conductivity Temperature Depth) profiles taken during six ship campaigns between 1998 and 2011 are used in this study (Table 2 and Fig. 1b) in combination with water mass fractions derived from tracer measurements (Sect. 2.3). Several additional CTD profiles were used in the inverse analysis (Sect. 2.4). The hydrographic surveys and instrumentation are described in Fahrbach et al. (2007), Dodd et al. (2012) and the available data links in Table 2. The station locations are given by the inverse model grid in Fig. 7 and were located along the lines in Fig. 1b.

\subsection{Velocity measurements}

Velocity was measured during the campaigns using Acoustic Doppler Current Profilers (ADCP), either as a vesselmounted ADCP (vmADCP) or a lowered ADCP (IADCP) along the line of CTD stations (Fig. 1b). The 1ADCP data were processed using the inverse method of Visbeck (2002). All velocity observations from the ship surveys were detided using predictions from the barotropic Arctic Ocean Tidal Inverse Model (AOTIM-5; Padman and Erofeeva, 2004). This model is only an approximation to the real ocean tides, which, in addition, have a baroclinic component dependent on the bathymetry and ocean stratification. However, the discrepancy between tides in the model and those measured by current meters moored along the east-west section near $79^{\circ} \mathrm{N}$ in the Fram Strait (Fig. 1) has been found to be about $0.01 \mathrm{~m} \mathrm{~s}^{-1}$ in the deeper layers of the section but less in the upper layers, where FW is observed (Behrendt, 2008). For the R/V Polarstern campaigns, the detided vmADCP profiles were median-averaged to hourly values; standard deviations for the data within each hour were generally below $0.1 \mathrm{~m} \mathrm{~s}^{-1}$. For the R/V Lance campaigns (2009 and 2011), only on-station vmADCP data were used and averaged for each station after detiding; the number of 5 min ensembles available for each station varied from only one to 25 . Shipbased velocity observations used in this study are listed by year in Table 3.

In addition, velocity observations from several moored instruments, located near $79^{\circ} \mathrm{N}$ in the Fram Strait (Fig. 1a), were averaged for a one-month duration centred around the time of each survey along the section (Table 3 ). The moored instruments included both point measurements from current meters by Aandera and Falmouth Scientific Instruments, and profiles from upward-looking ADCP. The Fram Strait mooring array is a collaboration between the Norwegian Polar Institute (Tromsø, Norway) and the Alfred Wegener Institute for Polar and Marine Research (Bremerhaven, Germany). 
Table 2. Data sources by year and campaign, showing references to available CTD and tracer (only 1998) data, where available; for $\delta^{18}$ O, nitrate and phosphate data from other years, please contact the authors of this work. Where applicable, a full citation of the database entry in the PANGAEA database is given; otherwise, the publication, where data were first shown. Observations from 2004 are only used indirectly due to reconstruction of $\delta^{18} \mathrm{O}$ values for 2005 from the corresponding relationship to salinity in 2004. All campaigns were carried out between June and September (see Dodd et al., 2012). The survey times refer only to those observations used in our analysis.

\begin{tabular}{lllll}
\hline Year & Survey times & Ship/Campaign & Reference & doi or contact \\
\hline 1998 & 1 Sep-10 Sep & PS ARK-XIV/2 & Schauer and Budéus (2010) & doi:10.1594/PANGAEA.759130 \\
$1998^{*}$ & 1 Sep-10 Sep & PS ARK-XIV/2 & Fahrbach and VEINS members (2010) & doi:10.1594/PANGAEA.759130 \\
$(2004)$ & 17 Jul-26 Aug & PS ARK-XX/2 & Schauer and Wisotzki (2010) & doi:10.1594/PANGAEA.742660 \\
2005 & 13 Aug-12 Sep & PS ARK-XXI/1b & Schauer and Rohardt (2010) & doi:10.1594/PANGAEA.742621 \\
2008 & 6 Jun-7 Jul & PS ARK-XXII/2 & Beszczynska-Möller and Wisotzki (2010) & doi:10.1594/PANGAEA.733424 \\
2009 & 2 Sep-23 Sep & LA Fram Strait 2009 & Dodd et al. (2012) & edmond.hansen@ npolar.no \\
2010 & 6 Sep-17 Sep & LA Fram Strait 2010 & Dodd et al. (2012) & edmond.hansen@ npolar.no \\
2011 & 23 Aug-1 Sep & LA Fram Strait 2011 & Dodd et al. (2012) & edmond.hansen@ npolar.no \\
\hline
\end{tabular}

Entries marked with * refer to nitrate, phosphate and $\delta^{18} \mathrm{O}$ water sample measurements, all others denote temperature and salinity (CTD) profiles. Ship abbreviations are as follows: PS = R/V Polarstern LA = R/V Lance.

Table 3. Data sources by year and campaign, showing references to available velocity observations from the ship and from moorings, where available. Entries with a cruise label refer to ship-based observations, others refer to moored observations. At least one of the following references are given: a full citation of the database entry in the PANGAEA database; the publication, where data were first shown; the contact e-mail of the PI. Only the part of the velocity data from moorings in the central and Eastern Fram Strait up to 2010 are in the PANGAEA database. E-mail contacts are given for the moorings in 2011 and for all years in the Western Fram Strait. Ship abbreviations are the same as in Table 2. The mooring data were averaged over a time period of about one month, with the corresponding dates given under "survey times". These time periods are centred around the survey times given in Table 2.

\begin{tabular}{|c|c|c|c|c|}
\hline Year & Survey times & $\begin{array}{l}\text { Ship/Campaign/ } \\
\text { instrument }\end{array}$ & Reference & doi or contact \\
\hline 1998 & $1 \mathrm{Sep}-10 \mathrm{Sep}$ & $\begin{array}{l}\text { PS ARK-XIV/2 } \\
\text { vmADCP }\end{array}$ & Fahrbach (2005) & doi:10.1594/PANGAEA.318314 \\
\hline 1998 & 22 Aug-21 Sep & Moorings & Fahrbach et al. (2001) & $\begin{array}{l}\text { Rabe et al. (2012) and } \\
\text { edmond.hansen@ npolar.no }\end{array}$ \\
\hline 2005 & 10 Aug-10 Sep & $\begin{array}{l}\text { PS ARK-XXI/1b } \\
\text { vmADCP }\end{array}$ & Schauer and Rohardt (2010) & hannelore.witte@awi.de \\
\hline 2005 & 13 Aug-12 Sep & Moorings & $\begin{array}{l}\text { Holfort et al. (2008) } \\
\text { Schauer and Beszczynska-Möller (2009) }\end{array}$ & $\begin{array}{l}\text { Rabe et al. (2012) and } \\
\text { edmond.hansen@ npolar.no }\end{array}$ \\
\hline 2008 & 6 Jun-7 Jul & $\begin{array}{l}\text { PS ARK-XXIII/2 } \\
\text { vmADCP }\end{array}$ & Beszczynska-Möller and Wisotzki (2010) & hannelore.witte@awi.de \\
\hline 2008 & 6 Jun-7 Jul & Moorings & $\begin{array}{l}\text { de Steur et al. (2009) } \\
\text { Schauer and Beszczynska-Möller (2009) }\end{array}$ & $\begin{array}{l}\text { Rabe et al. (2012) and } \\
\text { edmond.hansen@ npolar.no }\end{array}$ \\
\hline 2009 & $2 \mathrm{Sep}-23 \mathrm{Sep}$ & $\begin{array}{l}\text { LA Fram Strait } 2009 \\
\text { vmADCP }\end{array}$ & N/A & edmond.hansen@npolar.no \\
\hline 2009 & 2 Sep-23 Sep & $\begin{array}{l}\text { LA Fram Strait } 2009 \\
\text { lADCP }\end{array}$ & N/A & edmond.hansen@npolar.no \\
\hline 2009 & 29 Aug-28 Sep & Moorings & Beszczynska-Möller et al. (2012) & $\begin{array}{l}\text { Rabe et al. (2012) and } \\
\text { edmond.hansen@ npolar.no }\end{array}$ \\
\hline 2010 & $6 \mathrm{Sep}-17 \mathrm{Sep}$ & $\begin{array}{l}\text { LA Fram Strait } 2010 \\
1 \text { ADCP }\end{array}$ & N/A & edmond.hansen@npolar.no \\
\hline 2010 & 28 Aug-27 Sep & Moorings & Beszczynska-Möller et al. (2012) & $\begin{array}{l}\text { Rabe et al. (2012) and } \\
\text { edmond.hansen@npolar.no }\end{array}$ \\
\hline 2011 & 23 Aug-1 Sep & $\begin{array}{l}\text { LA Fram Strait } 2011 \\
\text { vmADCP }\end{array}$ & N/A & edmond.hansen@npolar.no \\
\hline 2011 & 13 Aug-12 Sep & Moorings & N/A & $\begin{array}{l}\text { gerd.rohardt@awi.de and } \\
\text { edmond.hansen@npolar.no }\end{array}$ \\
\hline
\end{tabular}




\subsection{Tracers and liquid freshwater component calculations}

Dodd et al. (2012) calculated fractions of liquid freshwater (LFW), meteoric water (MW), Pacific Water (PW) and net sea ice melt (SIM). The methodology to calculate these water masses relies on observations of salinity, nitrate, phosphate and oxygen isotope ratio $\left(\delta^{18} \mathrm{O}\right)$ at several CTD profile locations (Fig. 1a and Dodd et al., 2012).

This method uses a system of linear equations (endmember balance) to derive the aforementioned water mass fractions and fractions of Atlantic Water (AW) from each observed tracer, assuming certain end-member values for each tracer (see also Ekwurzel et al., 2001; Jones et al., 2008a; Yamamoto-Kawai et al., 2008). In addition to further years of observations, the main difference to previous work (Dodd et al., 2009; Rabe et al., 2009) is the inclusion of nitrate and phosphate observations to distinguish PW in the end-member balance. $\delta^{18} \mathrm{O}$ for the SIM end-member was set to a constant value, rather than relating it to the surface value of each profile. The reason for this is that, in contrast to studies in regions of ice formation, melt and formation of sea ice occurring in the Fram Strait are likely to have originated in regions away from the strait (Dodd et al., 2012). The salinity of SIM was set to 4 instead of 3, using the value by Østlund and Hut (1984), as observations are, as yet, insufficient to determine the average salinity of sea ice across the Arctic (Dodd et al., 2012). Note that observations from 2004 are used indirectly in this study due to the reconstruction of $\delta^{18} \mathrm{O}$ values for part of the section in 2005 from the corresponding relationship to salinity in 2004 (Rabe et al., 2009; Dodd et al., 2012). The data used in this study to obtain LFW and component fractions are a subset of those presented in Dodd et al. (2012) (see their figure 2 for data locations); please refer to Dodd et al. (2012) for further details of tracer measurements and calculation of the fractions from the end-member balance.

\subsection{Inverse model and water mass transports}

We use an inverse analysis model, the Finite Element Section model (FEMSECT; Losch et al., 2005), to obtain a physically consistent estimate of meridional velocity and transport from our observations during each survey. This is different from a simulation model, where data is only indirectly used to provide initial conditions and forcing at the boundaries. The model uses the baroclinic thermal wind equation as its physical basis, additionally allowing a non-zero barotropic velocity (Losch et al., 2005; Rabe et al., 2009). One of the advantages of FEMSECT over other inverse models is the use of finite elements and a triangular grid, that allows for a better representation between stations near the seafloor (Losch et al., 2005). In the following, we will refer to "observed" velocities, and volume and water mass transports as those from the inverse solution, unless stated otherwise. a)
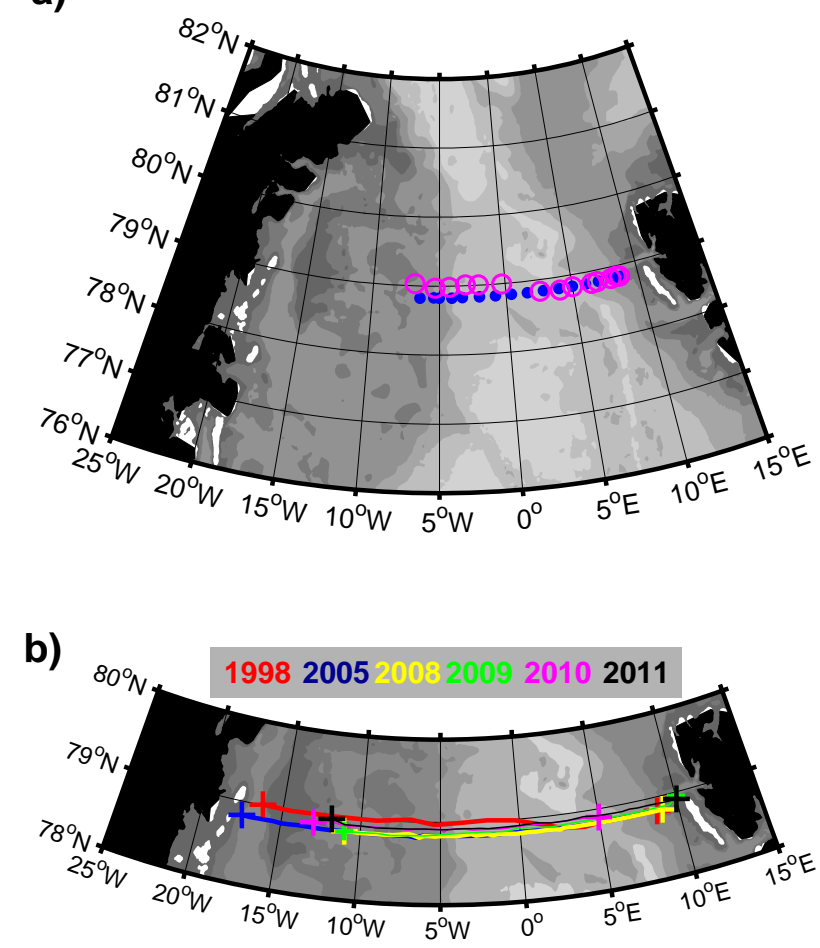

Fig. 1. Maps of (a) the locations of moorings for velocity measurements, for 1998 by circles, all other years by dots; (b) section lines for samples of $\delta^{18} \mathrm{O}$, nitrate and phosphate, where different years are indicated by colour as shown (see Fig. 2 in Dodd et al., 2012, for sampling locations along each section). Bathymetry shading in gray at intervals 100, 200, 1000, 2000 and $3000 \mathrm{~m}$ (from IBCAO, Jakobsson et al., 2008).

The FEMSECT grids are based on the hydrographic stations, as in Losch et al. (2005) and Rabe et al. (2009). The CTD data were subsampled in the vertical to save computation time (experiments with a vertical resolution equal to that of the CTD profiles showed not significant difference in our transport estimates). These grids are shown for each survey in Fig. 7. The grids have fixed depth levels and extend from $5 \mathrm{~m}$ depth to the seafloor (bottom of the CTD profiles). The vertical resolution of the grids ranges from $5 \mathrm{~m}$ near the surface to $100 \mathrm{~m}$, which is the resolution between $400 \mathrm{~m}$ below the surface and the seafloor (if the seafloor is deeper than $400 \mathrm{~m})$.

In addition to the shipboard observations (profile locations are shown by green dots in Fig. 7), time-averaged velocity measurements from moored instruments were used in the inverse analysis (instrument locations are shown by red circles in Fig. 7). Unlike in Rabe et al. (2009), where the average over a whole calendar month close to the ship survey was chosen, we averaged the velocity over a one-month period centered around the duration of that part of the survey used in our analysis. Any short gaps in the moored instrumental record due to consecutive recovery and deployment of the 

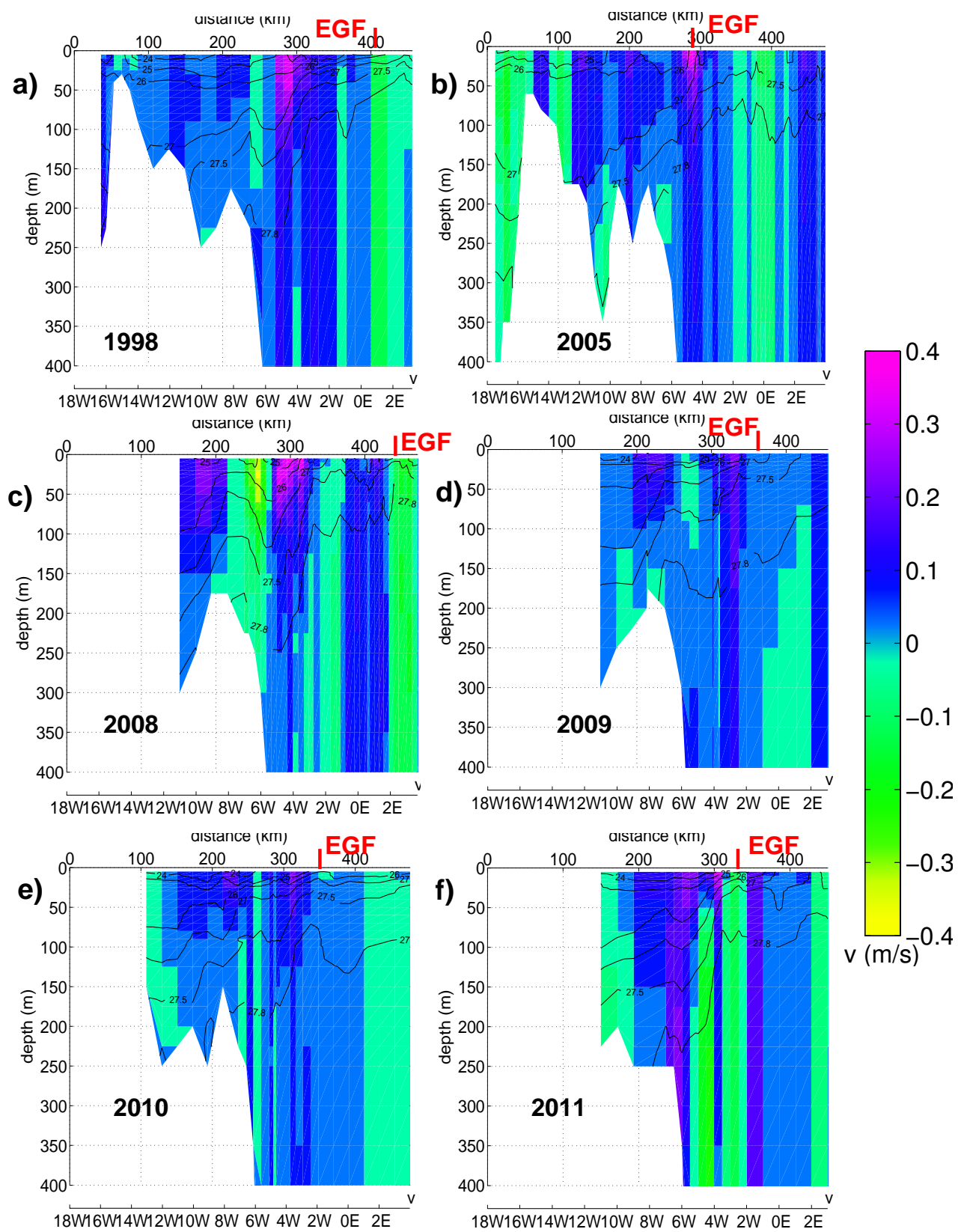

Fig. 2. Meridional velocity sections along the Western Fram Strait from the inverse solution: (a) 1998, (b) 2005, (c) 2008, (d) 2009, (e) 2010 and (f) 2011. Velocity is positive southward. Contours represent potential density from the inverse solution. Potential density is given in $\sigma$ notation, as departures from $1000 \mathrm{~kg} \mathrm{~m}^{-3}$. The position of the East Greenland Front, here defined as the westernmost surface outcrop of the zero isotherm, is marked by the thick vertical line next to "EGF".

systems were filled by linear interpolation in time; these gaps were no longer than 14 days. Longer gaps were left in the time series; for example, due to failure of an instrument for a whole deployment period. We only used velocity data from those moored instrument records where at least 14 days were observed within the one-month time period associated with each survey. We chose this method to obtain a good representation of the flow at the time of the survey while still using an average of several days or weeks to avoid shorter term fluc- tuations, such as tides, affecting the final velocity estimate. One of the strengths of this inverse method is to combine instantaneous measurements with more scarcely spaced timeaveraged observations to best represent the synoptic state of the part of the ocean under study for the duration of the survey. For further explanation of the method, see Losch et al. (2005). We used the same a priori observational errors in FEMSECT as Rabe et al. (2009). These errors determine the weighting of the velocity data and the final error estimate in 
the inverse solution and were taken to be $0.01 \mathrm{~ms}^{-1}$ for the mooring data and $0.1 \mathrm{~ms}^{-1}$ for vmADCP and lADCP data. Testing inverse solutions with a doubled a priori error for vmADCP and 1ADCP did not significantly change the final solution.

To calculate LFW component transports, each value of a component fraction was linearly interpolated onto the inverse model grid and multiplied by the volume transports in each grid triangle. We used only fraction data between $300 \mathrm{~m}$ and the surface, in accordance with Dodd et al. (2012), except for the deep channel in the west of the 2005 section. The near-surface sampling gap of the CTD profiles and bottle samples was filled by assuming the transport between the topmost cells in the FEMSECT grid and the surface to be constant.

\subsection{Transport uncertainties}

FEMSECT provides an error estimate for the inverse solutions of each survey based on the spatial coverage of the observations, the consistency of the final solution with all observations and the error associated with each type of observation; the details of this method can be found in Losch et al. (2005).

We are using a subset of the dataset in Dodd et al. (2012) in combination with our transport estimates. Therefore, the error in the LFW component transports is a combination of the error from the inverse analysis and the error in the LFW component fractions from the end-member equations used by Dodd et al. (2012) to calculate the fractions. From sensitivity analysis of the end-member equations, Dodd et al. (2012) estimated a maximum error of $1 \%$ for MW, $1 \%$ for SIM, $10 \%$ for PW and $10 \%$ for AW. For MW and SIM, the errors in the fractions are much lower than the errors in the corresponding volume transports from the inverse model. Hence, we expect the combined transport error of MW and SIM transports to be almost the same as the error from the inverse estimate. For PW transports, the errors in the fractions are considerably higher, so that the combined error would be, at maximum, double the error from the inverse estimate in all years. For the 2005 survey, Rabe et al. (2009) found a potential overestimate of MW transports and an underestimate of FSIM (contribution of SIM to freshwater) transports by $20 \%$ and $28 \%$, respectively. This was due to the reconstruction of $\delta^{18} \mathrm{O}$ values from salinity data, based on their linear relationship in the 2004 survey. The error estimates of the water mass transports due to the combination of errors from the water mass fraction calculation and from the inverse estimate are listed in Table 4; for 2005, alternate MW and SIM transports are given to account for the potential bias. Note that we will refer to the LFW and component transports as "water mass transports", although we give these in units of $\mathrm{mSv}$ or $\mathrm{km}^{3} \mathrm{yr}^{-1}$. The terminology is used to distinguish these transports from the volume transports, given only by the velocity and the dimensions of the grid of the inverse solution.
The effect of the near-surface sampling gap $\left(\delta^{18} \mathrm{O}\right.$ and nutrients) can be represented by the difference in section transports (see Sect. 3.2.2 for definition) with and without extrapolation near the surface. For MW transports, for example, this difference is $5 \mathrm{mSv}$, leading in an underestimate of southward transports if the sampling gap is not filled. Furthermore, we do not expect the stratification to have been high enough to reach an average salinity in the $5 \mathrm{~m}$ directly below the surface of half the salinity in the topmost cells of the FEMSECT grid $(5-10 \mathrm{~m})$ depth). Any shallow meltwater lenses, where a lower salinity could occur, were likely very shallow (1$2 \mathrm{~m}$ ) and scattered in small pockets along the section, so that they do not represent the typical average salinity in the $5 \mathrm{~m}$ directly below the surface during the surveys. We therefore assume that the transport error due to the surface sampling gap, if the transports are extrapolated into the gap, is well below the final error estimates for all surveys (Table 4).

It is not possible to estimate the error due to the temporal sampling gaps in the moored instrumental records. Hence, only moored velocity records with at least 14 days of observed data were used, as mentioned in Sect. 2.4.

As shown in Rabe et al. (2009), the combination of both shipboard and moored velocity records yields the smaller error in the inverse solution; in particular, the error is smaller than in solutions where shipboard velocities are not used. This was also found for the inverse solutions presented in this work (comparison not shown). The use of different types of ADCP data during the survey (vmADCP, 1ADCP) does not require a different a priori error estimate for the velocity input to FEMSECT. This is due to the fact that this error, based on variability during the one-month time period, is an order of magnitude higher than the instrumental measurement error. All a priori errors for the observations contributing to the inverse estimate, temperature, salinity and velocity from different sources, are the same as in Rabe et al. (2009).

The spacing of the velocity data in the grid of the corresponding FEMSECT solution and the consistency of this data with the final solution is represented in the FEMSECT error estimate.

Error estimates for the mean transports for each quantity in Table 4 are represented by the the mean of the corresponding transport errors from all surveys added to the variability of the transports between surveys. The variability is represented by twice the standard error of the mean, i.e. twice the standard deviation of each set of six transport values divided by $\sqrt{6}$, where the latter refers to the number of surveys; this error due to transport variability gives a $95 \%$ confidence range.

\section{Presentation and discussion of results}

\subsection{Velocity}

The density contours in the inverse solution of our observations (Fig. 2) generally show a front around 3 to $5^{\circ} \mathrm{W}$. This 
Table 4. Observed volume transports of LFW components between $10.6^{\circ} \mathrm{W}$ and $4^{\circ} \mathrm{E}$ for each year. Transport values are given in mSv; in addition, mean values in "()" are given in $\mathrm{km}^{3} \mathrm{yr}^{-1}$. Negative FSIM transports represent positive FIFB transports. Transport errors are also given. These incorporate both errors from the inverse volume transports and from the fractions from the end-member equation. The combined errors from the inverse and the end-member equations for LFW components are discussed in Sect. 2.5. The errors for each transport and survey are almost the same as the error from the inverse estimate, with the exception of FPW and PW transports; here, the error shown is about twice the error from the inverse estimate alone. There is a potential overestimate of MW transports and underestimate of FSIM transports in 2005 by about $20 \%$ and $28, \%$, respectively, due to the reconstruction of $\delta^{18}$ O values from salinity data (see Rabe et al., 2009). This is denoted by the transport values on the line starting with $2005^{*}$. The mean transports are the arithmetic mean of all surveys for each water mass. For 2005, the estimate including the potential bias is also given. The errors of the mean transports for each quantity are here represented by the the mean of the corresponding transport errors from all surveys and the variability of the transports between surveys (twice the standard error of the mean, i.e. twice the standard deviation divided by $\sqrt{6}$, where the latter is due to the number of surveys; this error gives a $95 \%$ confidence range).

\begin{tabular}{llllll}
\hline Year & LFW & MW & FSIM & FPW & PW \\
\hline 1998 & $117 \pm 7$ & $99 \pm 7$ & $-68 \pm 6$ & $86 \pm 5$ & $1030 \pm 60$ \\
2005 & $93 \pm 8$ & $172 \pm 13$ & $-90 \pm 12$ & $10 \pm 1$ & $121 \pm 24$ \\
$2005^{*}$ & - & $138 \pm 13$ & $-65 \pm 12$ & - & - \\
2008 & $103 \pm 9$ & $156 \pm 14$ & $-75 \pm 7$ & $9 \pm 2$ & $265 \pm 38$ \\
2009 & $82 \pm 6$ & $112 \pm 9$ & $-40 \pm 4$ & $14 \pm 4$ & $109 \pm 18$ \\
2010 & $81 \pm 11$ & $103 \pm 16$ & $-38 \pm 7$ & $55 \pm 4$ & $172 \pm 50$ \\
2011 & $124 \pm 10$ & $120 \pm 11$ & $-51 \pm 5$ & $653 \pm 48$ \\
\hline Mean & $100 \pm 23(3160 \pm 730)$ & $127 \pm 36(4000 \pm 1140)$ & $-61 \pm 23(-1910 \pm 720)$ & $33 \pm 28(1030 \pm 875)$ & $391 \pm 332(12300 \pm 10500)$ \\
Mean* & - & $122 \pm 29(3820 \pm 919)$ & $-56 \pm 18(-1780 \pm 570)$ & - & - \\
\hline
\end{tabular}

front represents the boundary of cold Polar Surface Water in the west and warmer, saltier waters of Atlantic origin in the Central and Eastern Fram Strait (Schlichtholz and Houssais, 2001; Schauer et al., 2004; Beszczynska-Möller et al., 2012). Our results show that the horizontal location of this front, defined as the surface outcrop of the zero isotherm (Schlichtholz and Houssais, 2001), varies between the surveys. This is in agreement with observations by Aagaard and Coachman (1968), who found the location of the front to be variable in time. A surface-intensified, southward current around the front is evident in our observations for all surveys, representing the core of the EGC, generally found over the East Greenland continental slope around 3 to $4^{\circ} \mathrm{W}$ (Foldvik et al., 1988; Fahrbach et al., 2001; BeszczynskaMöller et al., 2012). Opposing currents occurred in all years, suggesting the presence of horizontal recirculation or eddies (Fig. 2). The density field varied greatly between the different surveys, leading to different horizontal density gradients and, hence, different baroclinic velocities (Fig. 3) around the core of the EGC: in 2009, 2010 and 2011, horizontal gradients of density were smaller than in the remaining years, leading to lower peak velocities. Strongest horizontal density gradients were evident in 1998 and 2008, due to the presence of a strong meridional recirculation or eddy. The baroclinic component (Fig. 3) is of the same order of magnitude as the total (barotropic + baroclinic, Fig 2). The difference between the velocities in Figs. 2 and 3, the barotropic flow, is strongest in 2011. In all years, barotropic flows of similar magnitude as the baroclinic flows occur. This is in agreement with previous observational analyses (e.g. Fahrbach et al., 2001) and theoretical considerations regarding the boundary cur- rent around the Arctic basins and the Nordic Seas (Aaboe and Nost, 2008; Aaboe et al., 2009); in particular, Aagaard and Coachman (1968) already observed that the EGC shows this mixture of barotropic and baroclinic flow during summer, whereas their winter observations showed largely barotropic flow. Previous studies indicate that effects from both atmospheric pressure patterns and bottom density influence the barotropic flow (e.g. Schlichtholz, 2005). The baroclinic flow is forced by the thickness of the Polar Surface Water layer in the Arctic, via the hydraulically controlled flow in the Fram Strait (e.g. Rudels, 2010) as well as wind-induced Ekman transports. However, little is known about the effect of the latter on the shelf in the Western Fram Strait, and only in the Eastern Fram Strait have Ekman transports been observed to affect the mesoscale variability on timescales of 1-2 months (Jónsson et al., 1992).

\subsection{Transports of liquid freshwater and components}

\subsubsection{Distribution along the section}

The meridional transports of all LFW components approximately add up to zero west of $10.6^{\circ} \mathrm{W}$ in 2005 (see also Rabe et al., 2009). Therefore, we will reference all our transports to this longitude. The transports cumulated eastward from this longitude along the section varied strongly between $8^{\circ}$ and $3^{\circ} \mathrm{W}$ (Fig. 4). This was due to north-/southward alternating currents around the core of the EGC (Fig. 2), where the freshwater inventories of each station were still of similar magnitude as further west (figure 9 in Dodd et al., 2012). Further east, the along-section variability was smaller, due to lower 

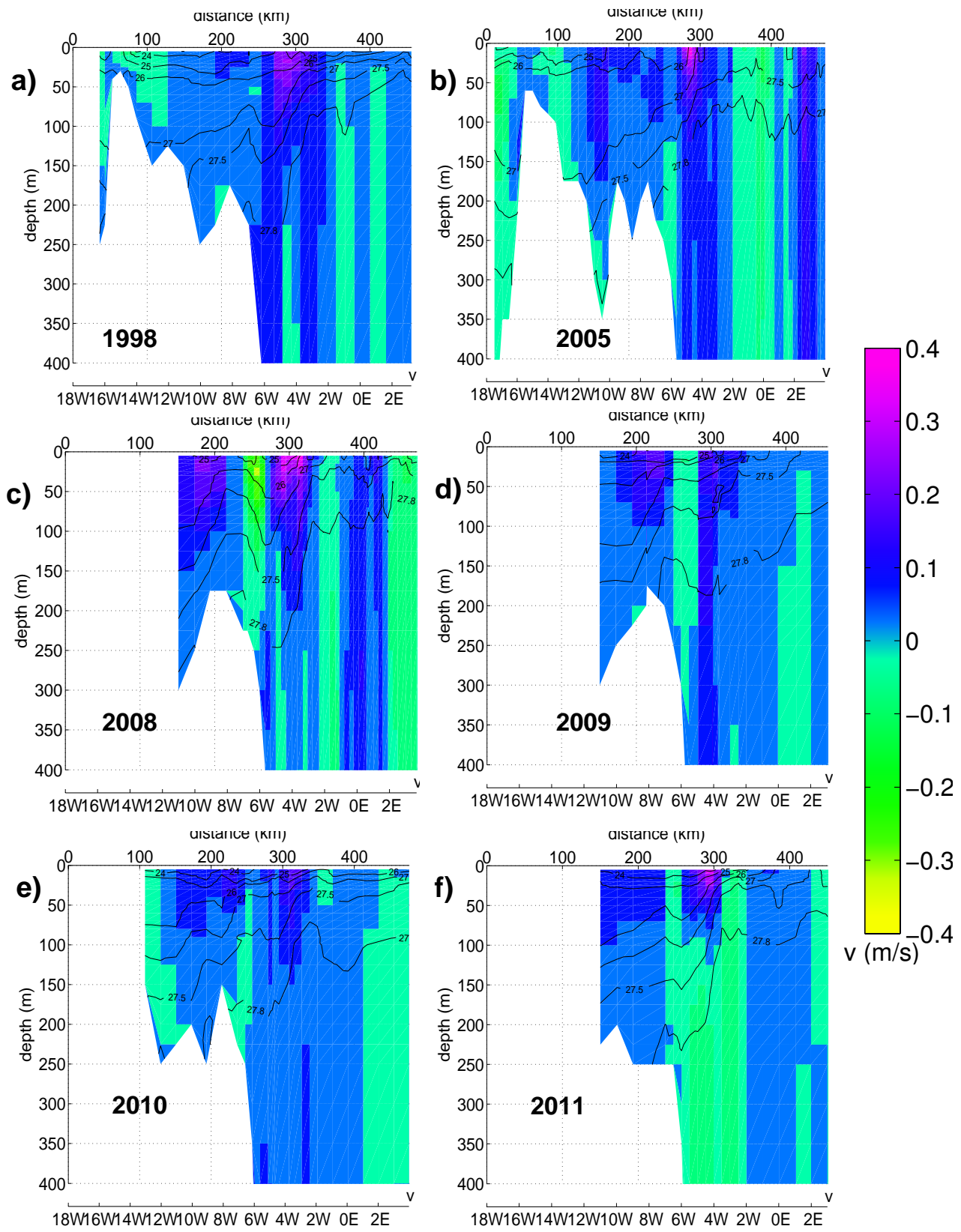

Fig. 3. Baroclinic component of the meridional velocity shown in Fig. 2: (a) 1998, (b) 2005, (c) 2008, (d) 2009 , (e) 2010 and (f) 2011.

station inventories. This generally resulted in small increases in transports to about $4^{\circ} \mathrm{E}$. The LFW transports in each year reflect the current structure of the velocity sections (Fig. 2) and the distribution of the LFW and component fractions in Dodd et al. (2012): opposing transport densities along the section are most noticeable for 2008 and 2011, whereas the remaining years showed only weak northward LFW transports east of $10.6^{\circ} \mathrm{W}$ (Fig. 4a). In 2009 and 2010, a combination of lower LFW concentrations near the surface (figsures 7, 10 and 12 in Dodd et al., 2012) and relatively weak velocities (Fig. 2d) lead to weaker LFW transport densities than in the remaining years (Fig. 4a).

As the fractions of FSIM are mostly negative throughout all surveys, this water mass is dominated by brine from sea ice formation and not by sea ice melt. Hence, it is convenient to express this water mass as net sea ice brine (IFB), equivalent to fractions of SIM multiplied by -1 . The contribution of positive values of IFB to LFW is then in the form of a freshwater deficit. This contribution is termed FIFB, equivalent to FSIM multiplied by -1 . Transports of FIFB are then simply transports of FSIM multiplied by -1 . Figure $4 \mathrm{c}$ 
a)

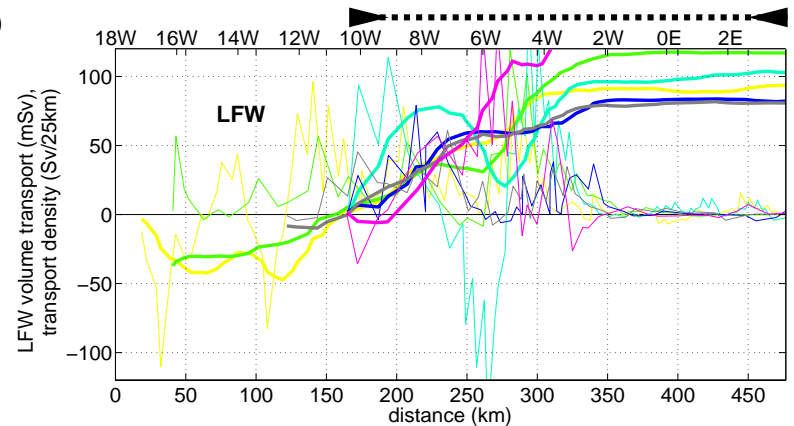

b)

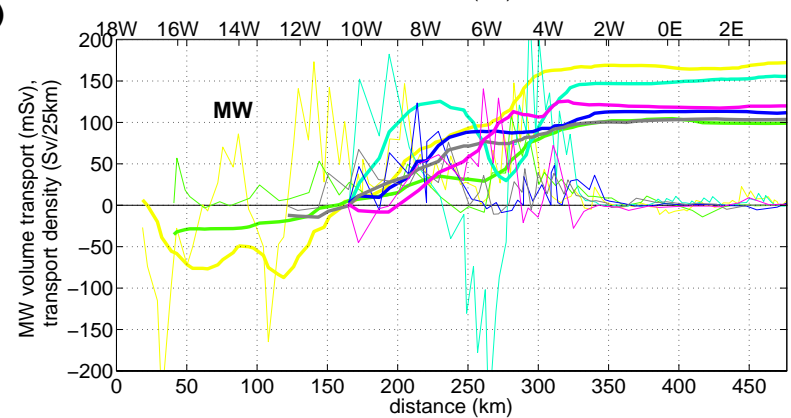

c)

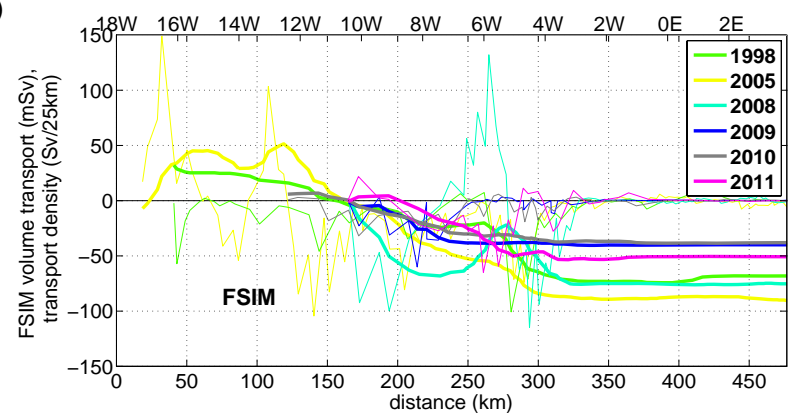

d)

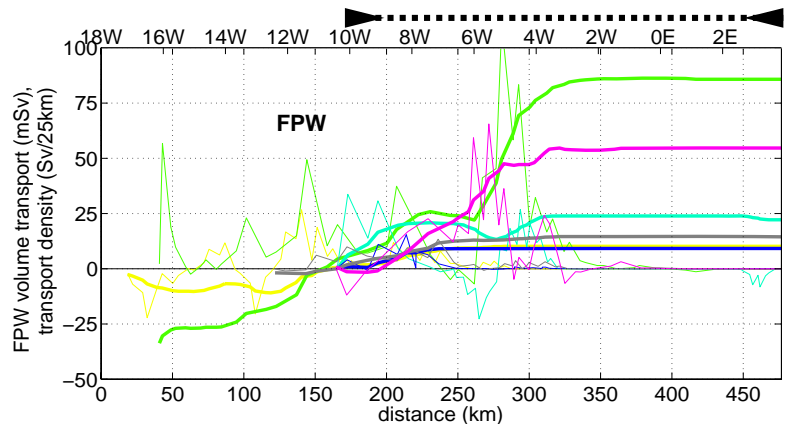

e)

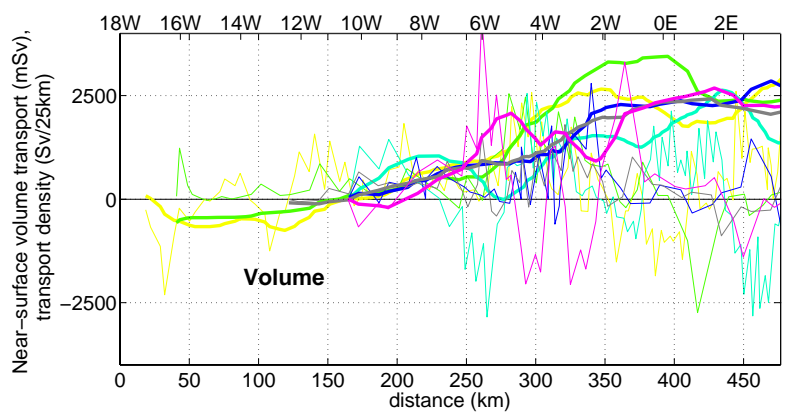

f)

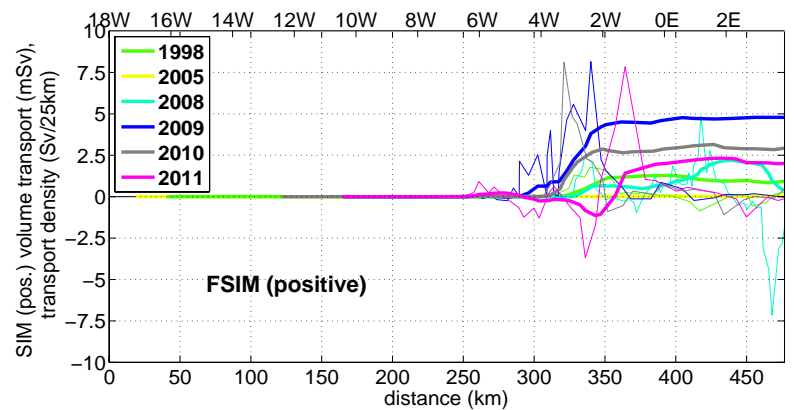

Fig. 4. Meridional transports of LFW components along the Western Fram Strait: (a) LFW, (b) MW, (c) FSIM, (d) FPW. The volume transport in the upper $300 \mathrm{~m}$ is shown in (e). Transport density is shown as thin lines and transports cumulated from $10.6^{\circ} \mathrm{W}$ as thick lines. Transports are positive southward. Results from different years are marked in colour, according to the legend in (e). Largely negative FSIM transports largely represent a southward transport of negative fractions of FSIM, dominated by sea ice brine, and not a northward transport of positive FSIM fractions. This is evident in the magnitude of transports of only positive fractions of FSIM in (f). The part of the section used for the "section" transports in Fig. 5 is marked by the thick dashed lines in (a) and (d).

shows that the transports are negative throughout most of the section, representing a southward transport of FIFB. That this transports is dominated by sea ice brine and not sea ice melt can be seen when looking at the transports of only positive fractions of FSIM (Fig. 4f), which are an order of magnitude lower than all other LFW component transports and largely occur east of the East Greenland Polar Front ("EGF" in Fig. 2). Only in 2008 is a strong northward transport (transport density) of FIFB evident in Fig. 4c, which is due to a recirculation or eddy around the core of the EGC (Figs. 2 and 4e).

\subsubsection{Average of all surveys}

The integrated LFW transport densities in the upper $300 \mathrm{~m}$ between $10.6^{\circ} \mathrm{W}$ and $4^{\circ} \mathrm{E}$, here termed "section" transports
(Fig. 5), averaged to $100 \pm 23 \mathrm{mSv}\left(3160 \pm 730 \mathrm{~km}^{3} \mathrm{yr}^{-1}\right.$, Table 4) for all six surveys. This is similar to the estimate by Rabe et al. (2009), who only considered 1998, 2004 and 2005; our estimate for two of those years increased due to various changes in the calculation of the inverse volume transports; for example, the time average for the mooring velocities has changed (Sect. 2.4). The average section LFW transport is at the higher end of published transport estimates from observations, which range from 28 to $95 \mathrm{mSv}$ (Dickson et al., 2007; Serreze et al., 2006), and from high-resolution, coupled ice-ocean simulations (Jahn et al., 2012).

In our surveys, mean MW section transports were about $130 \%$ of LFW transports and FIFB about $60 \%$ (FSIM about $-60 \%$ ), whereas FPW (PW contribution to LFW) only contributed about $30 \%$ (Table 4). 


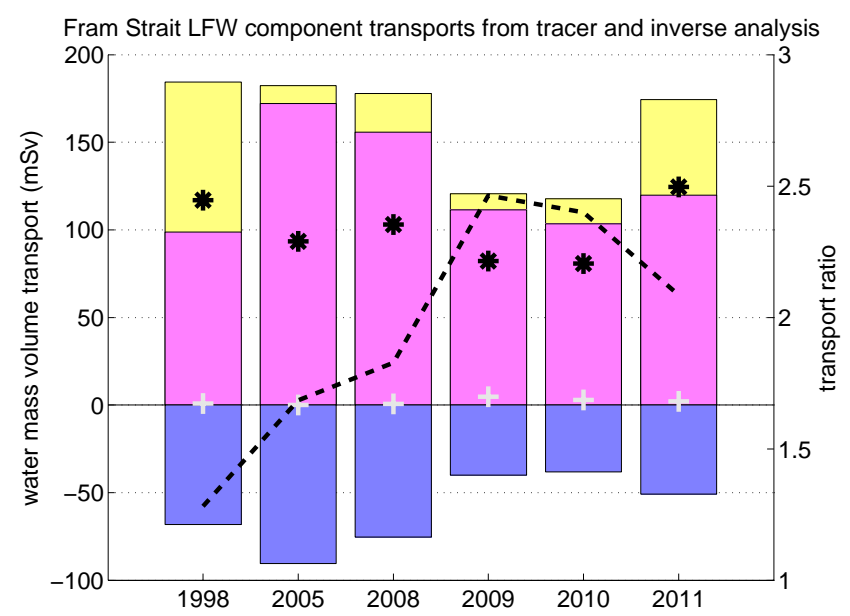

Fig. 5. Meridional section transports of LFW components in the Fram Strait between $10.6^{\circ} \mathrm{W}$ and $4^{\circ} \mathrm{E}$ for the years shown. The bars show the portion of every component: FPW (top, yellow), MW (magenta, middle) and FSIM (blue, bottom). The asterisks represent the LFW transport, the crosses the transports of only positive fractions of FSIM and the line the ratio of MW to FIFB transports.

\subsubsection{Variability}

LFW section transports varied between our six surveys but did not suggest any trend (Fig. 5 and Table 4). Considering year-round observations from moorings only (between about $7^{\circ} \mathrm{W}$ and the Greenwich Meridian), de Steur et al. (2009) showed that annual mean LFW transports in the Western Fram Strait did not show any clear trend from 1998 to 2008. According to de Steur et al. (2009) the majority of volume transport increases occurred in deeper layers, away from high LFW concentrations.

In our surveys, transports of MW and FIFB were highest in 2005 and 2008 (Fig. 4b and c), whereas FPW transports throughout the section were highest in 1998 (Figs. 4d and 5 for section transports). MW section transports followed the low LFW section transports in 2009 and 2010 but remained fairly low in 2011, despite higher LFW section transports. FIFB section transports were lower during the surveys in 2009, 2010 and 2011 than in 1998, 2005 and 2008. After 1998 , significant (with respect to the transport error) FPW section transports were observed again in 2008 and 2011, where the latter was more than half the transport value in 1998. The magnitude of our FPW transports has to be seen in the context of recent evidence of a potential overestimate of FPW inventories due to processes near the Laptev Sea continental slope (Bauch et al., 2011b). This may be reflected in the end-member balance calculations by Dodd et al. (2012). However, a large-scale model simulation with an ice-ocean coupled general circulation model, the North Atlantic-Arctic Ocean Sea Ice Model (NAOSIM, e.g. Karcher et al., 2005, 2006), indicates that the amount of water from the Bering Strait apparent in the Fram Strait increased from 2005 to
2011, with a temporary drop in 2009 and again a strong increase in 2011 (M. Karcher, personal communication, 2012). This is in agreement with our surveys. The model also supports our results with regard to high Bering Strait water content in the Fram Strait in 1998.

\subsubsection{Volume transports and inventories}

We expect some covariation of the LFW and component section transports with both the section volume transports in the upper $300 \mathrm{~m}$ (Fig. 6b) and the section inventories of LFW and components (Fig. 6a). We define a "section inventory" as the area integral in the upper $300 \mathrm{~m}$ along the section between $10.6^{\circ} \mathrm{W}$ and $4^{\circ} \mathrm{E}$.

In 2005 we observed higher section transports of MW as well as only negligible transports of FPW, compared to 1998 (Fig. 5). This is similar to the difference in the corresponding section inventories. On the other hand, 2008 shows section inventories of MW and FPW larger than or equal to 2005 (figure 13, Dodd et al., 2012), whereas the section transports of MW and FIFB were lower. In 2009, 2010 and 2011, the section transports of MW and FIFB were lower than in 2005 and 2008 due to reduced section inventories and smaller velocities (Fig. 2).

If section volume transports were constant between all surveys and only the water mass section inventories changed, we would expect the normalised water mass section transports to be about equal to the normalised water mass section inventories; i.e., all the points in Fig. 6a would lie approximately on a line from zero to unity. We can see that this is nearly the case, although the dots associated with FIFB, in particular, deviate most from this line.

Conversely, if water mass section inventories were constant and only the volume transports changed, all points in Fig. 6b should lie approximately on a line. This is clearly not the case.

As correlation or linear fits of results from only six surveys are statistically problematic, we instead look at the range of values covered by the water mass section inventories and water mass section transports: LFW section inventories changed by about $30-35 \%$ (see also figure 13 in Dodd et al., 2012) of the maximum (Fig. 6a) from all six surveys, as did the LFW section transports. MW and PW section inventories and transports also showed similar ranges of variability, over $45 \%$ and $90 \%$ of the maximum, respectively. Only FIFB section transports showed higher variability than the corresponding inventories, $45 \%$ as opposed to $60 \%$ of the maximum, respectively.

Our results suggest that the presence of LFW components in the Fram Strait has most influence on the water mass volume transports. However, individual years suggest a strong influence by local ocean dynamics in the Fram Strait on the LFW component transports; in particular, for FIFB. This is in agreement with interannual and seasonal LFW transports from model analyses (Lique et al., 2009; Jahn et al., 2010, 

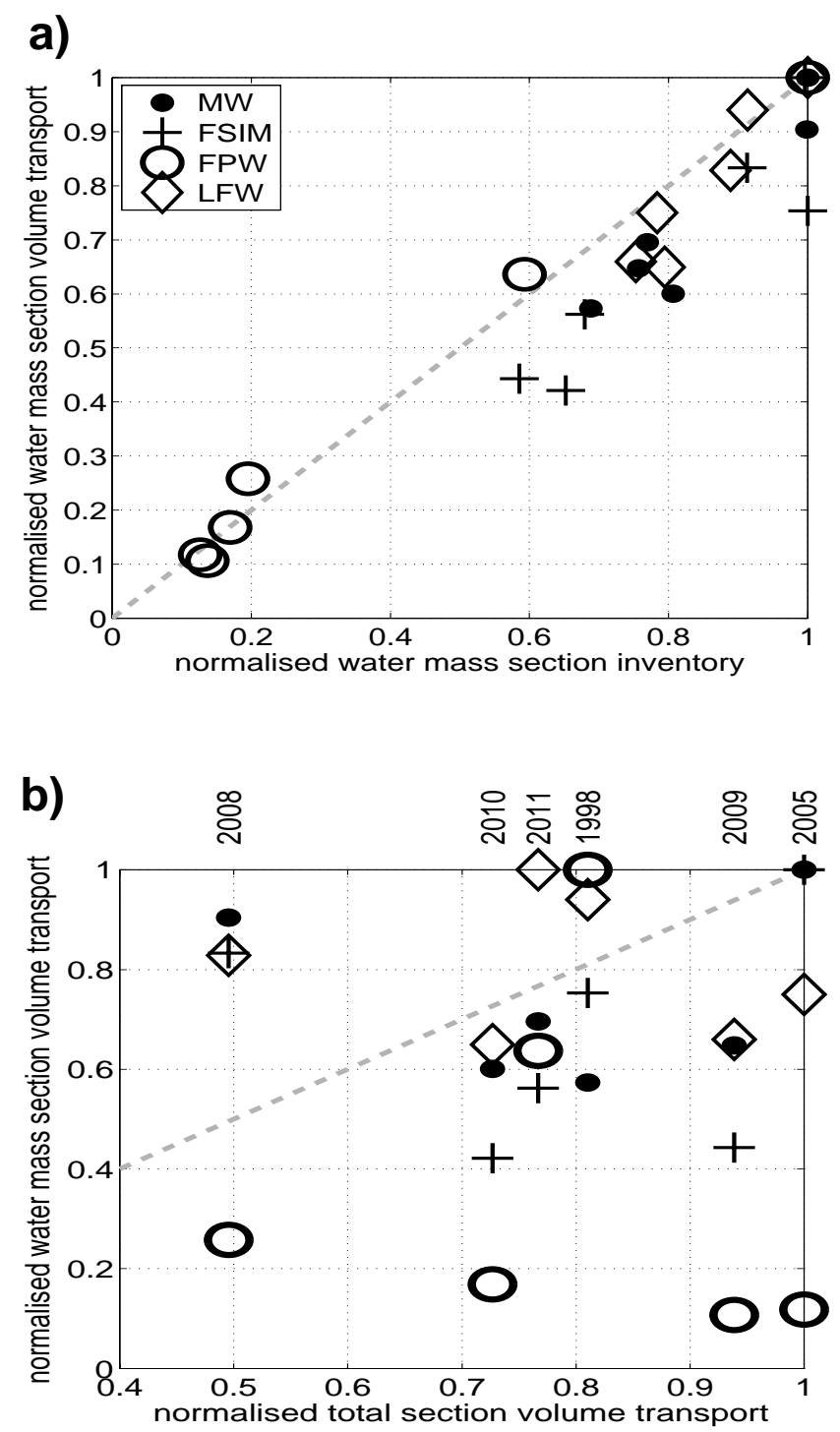

Fig. 6. Meridional section transports of LFW components vs. section inventories of LFW components (a). LFW component transports vs. volume transports in the upper $300 \mathrm{~m}$ (b). Here, section inventories and section transports were calculated between $10.6^{\circ} \mathrm{W}$ and $4^{\circ} \mathrm{E}$; the section inventories are based on the fractions of LFW components in Dodd et al. (2012). All values are normalised by the respective maximum of all six campaigns, so that the maximum section transport/inventory of each quantity is at unity. Inventories and transports of FSIM were multiplied by -1 (FIFB section inventories and transports). Symbols denote different transport components: MW (dots), FIFB (plus), FPW (circles) and LFW (diamonds). The thick grey line depicts an exact linear relationship between each quantity.

2012), and the seasonal cycle of LFW transports from yearround observations by the Fram Strait moorings between 2002 and 2007 (Jahn et al., 2012).

\subsubsection{Covariability of different LFW components}

Our results show that the ratio of MW to FIFB (black dashed line in Fig. 5) is about 2:1 in all of our surveys, except 1998. Previous studies have found that a similar ratio of MW to FIFB is generally observed in station or section inventories (Meredith et al., 2001; Dodd et al., 2009; Rabe et al., 2009) and section transports (Rabe et al., 2009). This has been attributed to processes in the Arctic Ocean "upstream" from the Arctic outflow in the Fram Strait. These processes occur both on the large scale, and in regions of origin and storage of the LFW components (see Sect. 4).

Although we have a limited amount of data, our results suggest that the ratio of MW to FIFB increased in time. Considering the error in this ratio due to the transport error (Table 4), we observe significantly different ratios in 1998 and 2009 , suggesting an increase from about $3: 2$ to $5: 2$. The ratios of the section inventories of MW and FIFB showed a similar behaviour, although the ratios cover a wider range (figure 15 in Dodd et al., 2012). This may be due to the fact that MW is more strongly affected by high baroclinic velocities near the surface, whereas most of the negative values of SIM are found around $50 \mathrm{~m}$ depth and deeper (Dodd et al., 2012; Rabe et al., 2009).

The presence of positive SIM fractions near the surface in 2009, 2010 and 2011, not present in previous years, suggests that some of the sea ice brine signal deeper down in the water column could have been diluted by additional sea ice melt. This would explain why in 2009, 2010 and 2011, the positive SIM section transports were somewhat higher than in previous years but still not much bigger than the transport error. Potential reasons for the addition of positive FSIM and for the lower FIFB section transports include a change in the production of sea ice in the shelf regions or a change in pathways or origin of MW and sea ice brine. This is supported by the fact that the strongest signals of positive and negative SIM occur at different depths, indicating that mixing occurred in regions of the Arctic where most of the sea ice is formed.

\subsection{Discussion}

Our results rely on six hydrographic surveys and one-month averages of mooring data. The error due to time variability and the synopticity of the hydrographic survey within the one-month time period is largely included in the error estimate from the inverse solution due to the appropriate setting of a priori errors of the temperature, salinity and velocity observations (Sect. 2.5). However, there is also seasonal variability in the freshwater transports. This has been found to be of similar magnitude as the interannual variability in transports based on year-round velocity observations from the moorings, spanning part of the section east of $6.5^{\circ} \mathrm{W}$ (de Steur et al., 2009). Our surveys were largely during August and September, except for 2008, which was during June 

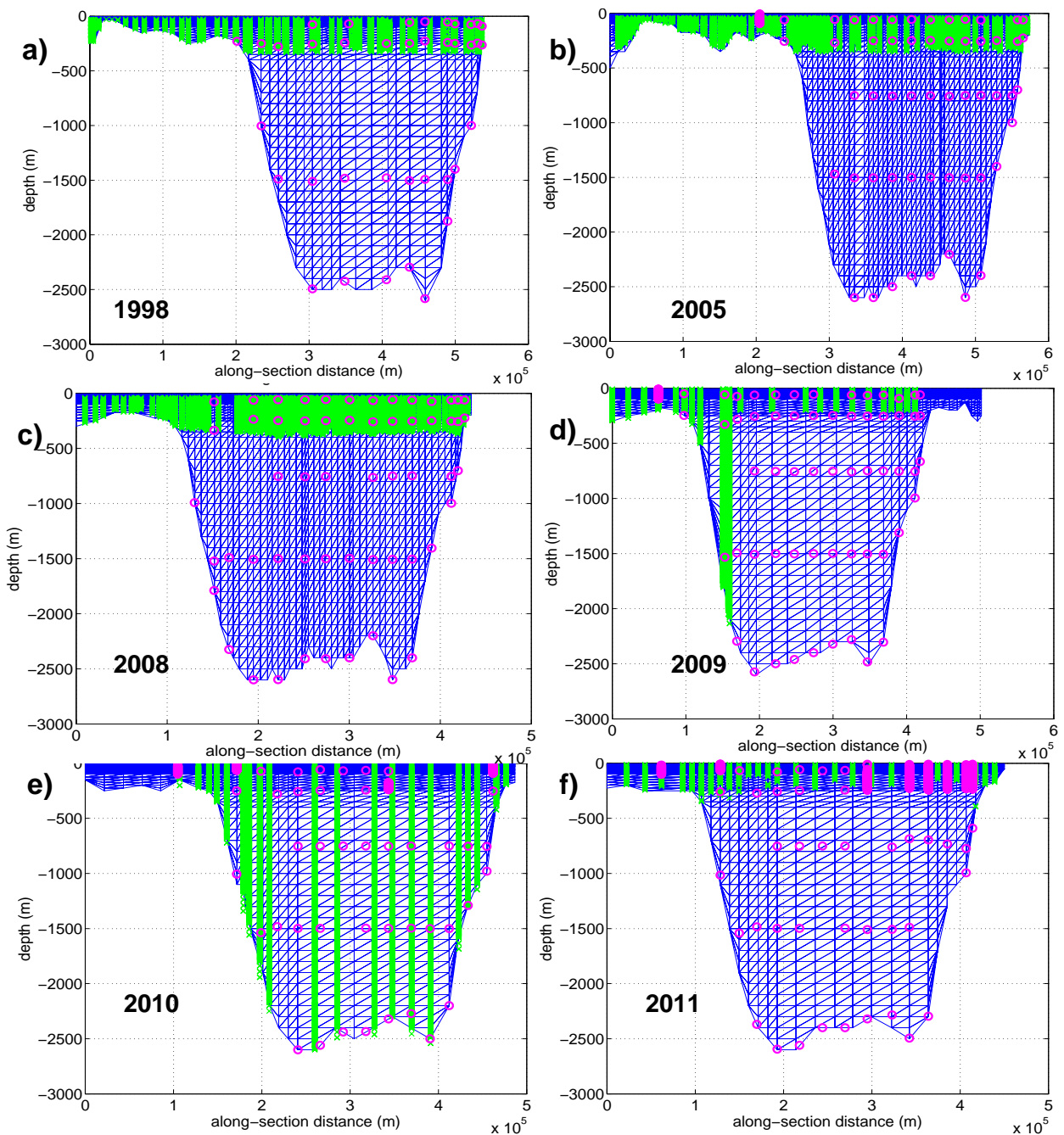

Fig. 7. FEMSECT grid used for the inverse solution of our hydrographic and velocity observations in each year: (a) 1998, (b) 2005, (c) 2008, (d) 2009 and (e) 2010. The grid nodes represent the CTD stations, subsampled in the vertical, the red circles the mooring-based velocities and the green crosses the shipboard velocities.

and July. We can, therefore, not exclude the possibility that differences in transports from the survey in 2008 and those in the remaining years are partly due to seasonal variability.

Furthermore, the NAOSIM model shows that LFW components advected through the transpolar drift may arrive in the Fram Strait in time-limited pulses; for example, Rabe et al. (2009) found that NAOSIM showed a pulse of MW arriving in late summer 2004, but the signal was not yet observed in the 2004 survey (see also Dodd et al., 2012).

Bearing in mind these caveats, we will not analyse time variability of atmospheric circulation patterns and regional sea level pressure changes in relation to transports in the Fram Strait using our six surveys. Instead, we will discuss our results in the context of specific changes in ocean circulation and advection of freshwater-related water masses on regional to Arctic-wide scales.

\section{Discussion within the large-scale context}

\subsection{Changes in the Arctic Ocean basins}

Our results in Sect. 3.2.4 indicate that the LFW component fractions strongly influence the LFW component transports in the Fram Strait. This is supported by the study of Arctic liquid freshwater storage and export in model simulations and moored observations, that partly focused on the Fram Strait (Jahn et al., 2012). Further studies of individual liquid freshwater components include the link of low FPW transports after 1998 and changes in the extent and the pathways of PW in the Arctic basins; in particular, a climate model simulation has shown that the pathways of PW exports from the Arctic are strongly related to the strength of the Beaufort Gyre (Jahn et al., 2010). Proshutinsky et al. (2009) observed a strong decrease in FPW in the Beaufort Gyre in the 
1990s, relative to previous decades, but only a lesser, subsequent reduction until 2007. Concurrently, LFW in the upper mixed layer increased. Proshutinsky et al. (2009) linked these processes to the strength of atmospheric cyclonicity in the Arctic through local Ekman Pumping. The strongly anticylonic atmospheric circulation in 2007 suggests that the Beaufort Gyre retained LFW, whereas the anomalously cyclonic winds in 2009 caused a release. On the other hand, Alkire et al. (2007) observed a return of PW in the Central Arctic in 2003/2004 where it had previously been absent since observations began in 2000. Their analysis also indicated that PW was advected westward along the Siberian continental slope before entering the Transpolar Drift from the East Siberian Sea. The observed return of PW to the Central Arctic and the dynamics of the Beaufort Gyre, implying a storage and release of PW depending on winds, may both have contributed to the advection of PW toward the Fram Strait. This is in line with our observations of PW transports being higher in our surveys in 2008 and 2011 than in 2005. Alkire et al. (2007) further suggest variability of the occurrence of PW in the Transpolar Drift on timescales of two or more years, shorter than the variability in the large-scale atmospheric circulation as represented by the Arctic Oscillation index (e.g. Thompson and Wallace, 1998). This is in line with the variability we observe in PW transports from our surveys after 2005.

The high MW transports in the Fram Strait in 2005 can be linked to strong pulses of river water leaving the Siberian shelves at the end of the 1990s, joining the Transpolar Drift (Anderson et al., 2004; Karcher et al., 2006; Jones et al., 2008a) and reaching the Fram Strait in 2004/2005 (Rabe et al., 2009). Concurrent with our 2005 peak in MW transports, an anomalously strong pulse of southward LFW transport was also observed on the other side of Greenland, in the Nares Strait (Rabe et al., 2010), suggesting a concurrent large-scale advection of MW toward the Arctic export passages. Nevertheless, this pulse does not appear to have drained the Central Arctic of freshwater for the coming years: in 2007 MW was still observed to be high north of the Siberian Islands near the Lomonosov Ridge, compared to observations from the mid-1990s (Abrahamsen et al., 2009). On the Amerasian side, from 1987 to 2007, Yamamoto-Kawai et al. (2009) observed an increase in MW in the center of the Beaufort Gyre. In 2010, the Eurasian Basin (European/Asian side of the Lomonosov Ridge) was observed to be fresher than in 2007/2008. This was attributed to an enhanced advection of freshwater from the Beaufort Gyre, due to a temporarily anomalous cyclonic circulation in the Arctic atmosphere (Timmermans et al., 2011). This is likely to have contained some of the MW accumulated in the Beaufort Gyre until 2007. Observations of dissolved Barium in 1998 (Taylor et al., 2003) suggest that most of the MW in the Fram Strait originates from Eurasian continental runoff. The above results are in agreement with the high MW transports in our surveys from 2005 and 2008, relative to the transports in the other surveys. Much of the MW in these years is likely to have originated from Eurasian rivers and to have been advected directly via the Transpolar Drift. The increase in LFW and components as well as the corresponding transports in 2011 suggest that some of this water was advected from the Beaufort Gyre.

The covariation of MW and FIFB section transports and inventories (Sect. 3.2.5) may be due to formation processes on the Siberian shelves (Bauch et al., 2009, 2011a). Within the Transpolar Drift, Jones et al. (2008a) observed IFB patches at depths below $50 \mathrm{~m}$ in the Eurasian Basin, vertically isolated from the much shallower summer surface mixed layer. Furthermore, summer observations in the shelf regions of the Laptev and Kara seas from 1999 to 2001 have shown that waters with salinities lower than 30 take different pathways from the shelf than those with higher salinities (Bauch et al., 2005). Stratification in the upper Arctic Ocean has been found to be enhanced in recent years; for example, Toole et al. (2010) found that even the top $50 \mathrm{~m}$ were much more strongly stratified in 2007 than in 1975 . This made subsurface temperature maxima inaccessible to surface mixing, at least during summer. Recently, in summer 2011, isolated subsurface temperature maxima have also been observed in the Eurasian Basin during the R/V Polarstern Transarc expedition. This suggests that sea ice brine may be advected in the Transpolar Drift from the Eurasian shelves to the Fram Strait without much on-the-way modification by sea ice melt near the surface, in particular during the last two decades.

Relative to the 1990s, NAOSIM suggests enhanced net sea ice melt on the Siberian shelves and in the region of the Chukchi Plateau, north of the Bering Sea and East Siberian Sea shelves, in the time period 2006-2008 (Rabe et al., 2011). Net sea ice melt has been shown to be rapidly advected from the Siberian shelves to the Fram Strait within the Transpolar Drift (Bauch et al., 2011b). In the Central Beaufort Gyre, observations show a reduction in sea ice brine between 1987 and 2007, while some additional sea ice melt was observed in 2006 and 2007 (Yamamoto-Kawai et al., 2009). This sea ice melt may have been released from the Beaufort Gyre and partly advected to the Fram Strait, in line with the observed freshening in the Eurasian Basin in 2010 (Timmermans et al., 2011). In addition, there is observational evidence of enhanced ice melt contributing to the increase in liquid freshwater in the upper basins on the Amerasian side of the Lomonosov ridge (Korhonen et al., 2012). Hence, we have potential remote sources for the enhanced sea ice melt in the Beaufort Gyre as well as on the Siberian shelves, and for the resulting decreased FIFB transports we observed in the Fram Strait in 2009/2010. MW and IFB have been shown to vary independently in the Canada Basin (Yamamoto-Kawai et al., 2009), unlike on the Siberian shelves (Bauch et al., 2011b). Therefore, the difference in MW to FIFB ratio in our 1998 and 2009 surveys suggests a difference in origin of MW and FIFB in the Fram Strait, which could have been caused by enhanced advection of water from the Canada Basin. However, if the majority of MW 
and FSIM/FIFB in the Fram Strait originated in the Canada Basin, we would expect the ratio to vary strongly in the future.

The freshening of the Eurasian Basin from 2007/2008 to 2010 (Timmermans et al., 2011) could also have had a dynamical influence on our transports: the additional freshwater could have increased the layer thickness of the polar mixed layer north of the Fram Strait. If it reached the Fram Strait in subsequent years, it could have forced an enhanced baroclinic transport (e.g. Rudels, 2010) of LFW through the Fram Strait in 2011; indeed, the baroclinic velocities were higher in 2011 than in the preceding two surveys (Fig. 3). In addition, the LFW increase could have supplied the increased LFW transports even without changes in Fram Strait volume transports.

\subsection{Changes in LFW imports to the Arctic}

In addition to shelf-basin exchange of MW, increased river discharge is a potential source for increased MW transports in our observations. Overeem and Syvitski (2010) found a $9.8 \%\left(5.5 \mathrm{~km}^{3} \mathrm{yr}^{-1}\right.$ or $\left.0.17 \mathrm{mSv}\right)$ increase in river discharge over the entire Arctic region from 1977 to 2007; an increase was also found when only data from the 1990s to 2007 were considered. If we consider the Arctic Ocean prior to 1977 to be our reference, the additional river input would have been about $5 \mathrm{mSv}$ in $30 \mathrm{yr}$ or $2 \mathrm{mSv}$ in the $13 \mathrm{yr}$ of our observations in the Fram Strait. Interannual variability in the discharge of several large Arctic rivers was shown by Overeem and Syvitski (2010) to be up to an order of magnitude higher than the corresponding trends over the $30 \mathrm{yr}$; however, not all rivers exhibited this degree of variability, and no time series of the Arctic-wide river discharge was presented in Overeem and Syvitski (2010). Based on the results shown in Overeem and Syvitski (2010), we conclude that both the $30 \mathrm{yr}$ increase as well as known variability in Arctic river runoff are usually well below the variability in MW transports that we observe. Hence, changes in river discharge into the Arctic are not likely to be a major cause for the variability of the LFW and component transports in the Fram Strait between 1998 and 2011.

Changes in PW and MW transports through the Fram Strait could potentially be due to changes in the flow from the Pacific into the Arctic through the Bering Strait. Indeed, the observed volume transport and LFW transport through the Bering Strait both increased from 1998 to 2011, although the increase in LFW transport was within the error margin of the estimate (Woodgate et al., 2006, 2012). Both studies observed up to about $1000 \mathrm{~km}^{3} \mathrm{yr}^{-1}(31 \mathrm{mSv})$ variability on timescales of 3-4 yr. This is above the error margin of their transport estimates and is significant with respect to the variability in MW and FPW section transports we observe.

Estimates from model simulations put the transit times of PW from the Bering Strait to the Fram Strait at around 5 to $10 \mathrm{yr}$ (Nguyen et al., 2011), in line with observational esti- mates for PW residence time in the Canada Basin $(11 \pm 4 \mathrm{yr}$; Yamamoto-Kawai et al., 2008). The high PW section transports we observed in 2011 as well as variability in section MW transports could be due to variability in the LFW transport through the Bering Strait. Furthermore, observations by Alkire et al. (2007) indicate that water from the Bering Strait was diverted onto the Siberian shelves and subsequently released into the basins around 2004. This could also have influenced the FPW transports we observed in our surveys in subsequent years.

\subsection{Exports from the Arctic and circulation at lower latitudes}

A peak in MW and SIM concentrations was observed in the EGC in the Denmark Strait in 2005, relative to observations in 2004 and 2008 (Cox et al., 2010). Cox et al. (2010) attribute this observation to an enhanced export of sea ice in the EGC through the Fram Strait. Our observations also show peaks in the transports of MW and IFB in 2005, which would influence the signal arriving in the Denmark Strait. The advective timescale in the EGC from the Fram Strait to the Denmark Strait has been estimated to be of the order of a few months (Dodd et al., 2009). Hence, our transport results indicate that the MW and SIM peak found in the Denmark Strait in 2005 is at least to some extent due to changes in the LFW transport composition in the Fram Strait. Furthermore, Sutherland et al. (2009) found high levels of PW in the vicinity of the Denmark Strait during the 1990s and a decline to much lower levels in 2002 and 2004, which is in agreement with our transport analysis. They further related these levels of PW to the Arctic atmospheric circulation represented by the Arctic Oscillation index (e.g. Thompson and Wallace, 1998).

Several ice-ocean general circulation models show a decrease in net Arctic LFW exports since the 1990s, in particular through the Canadian Arctic Archipelago (Jahn et al., 2012). At the same time, the LFW storage in the upper Arctic Ocean basins increased between the 1990s and 2006-2008 (Rabe et al., 2011), further supported by several ice-ocean model simulations (Jahn et al., 2012). The results presented here and in de Steur et al. (2009) do not indicate a trend in the export of LFW and components through the Fram Strait into the Nordic Seas and the North Atlantic. Whether any decrease in LFW export from the Arctic has occurred on the other side of Greenland is, as yet, unknown. Only model simulations and hydrographic observations hint at a decrease of southward LFW transports through the Davis Strait (P. Holliday, personal communication, 2012).

\section{Summary and concluding remarks}

We present southward liquid freshwater component transports from observations in the Western Fram Strait between 
June and September, spanning more than a decade. The transports were derived using liquid freshwater component fractions from $\delta^{18} \mathrm{O}$ and nutrient observations (Dodd et al., 2012) together with velocities from an inverse model; the latter combines six hydrographic / velocity sections from observational campaigns between 1998 and 2011 as well as concurrent records from moored instruments.

- Averaging all six observational sections, we find a southward liquid freshwater transport between $10.6^{\circ} \mathrm{W}$ and $4^{\circ} \mathrm{E}$ of $100 \pm 23 \mathrm{mSv}$ $\left(3160 \pm 730 \mathrm{~km}^{3} \mathrm{yr}^{-1}\right)$, relative to a salinity of 34.9 . The average liquid freshwater transport consists of $125 \pm 39 \mathrm{mSv}\left(3910 \pm 1140 \mathrm{~km}^{3} \mathrm{yr}^{-1}\right)$ meteoric water, $59 \pm 26 \mathrm{mSv}\left(1845 \pm 720 \mathrm{~km}^{3} \mathrm{yr}^{-1}\right)$ freshwater deficit due to net sea ice brine (net effect of sea ice formation and melt), $391 \pm 332 \mathrm{mSv}\left(12300 \pm 10500 \mathrm{~km}^{3} \mathrm{yr}^{-1}\right)$ Pacific Water transport contributes $33 \pm 28 \mathrm{mSv}$ $\left(1030 \pm 875 \mathrm{~km}^{3} \mathrm{yr}^{-1}\right)$ to the liquid freshwater transport. The high error in the latter stems from the strong variation in Pacific Water concentrations between the surveys.

- Liquid freshwater component concentrations or inventories strongly influenced the liquid freshwater component transports we observed in our sections. However, changes in volume transports were also found to have an influence in individual surveys; in particular, for transports of net sea ice brine. Comparison of our results with other studies of observations and model simulations indicates that PW transports were influenced by advection from other regions of the Arctic Ocean, primarily the Beaufort Gyre. Liquid freshwater release near the Siberian shelves and advection from the Beaufort Gyre were both likely to have influenced changes in the transports of meteoric water and net sea ice brine.

- Our results suggest that that section transports of meteoric water and net sea ice brine covary in time, as do the corresponding section inventories. This is in agreement with joint processes of these water masses in the production regions of sea ice brine and concurrent pathways through the Arctic Ocean before arriving at the Fram Strait. Increased stratification observed in the Amerasian and Eurasian Arctic in the first decade of the 2000s suggests that sea ice brine may generally be advected from the Siberian shelves in the Transpolar Drift to the Fram Strait with little or no alteration by surface processes on the way.

- We observed a significantly higher ratio of meteoric water to net sea ice brine transports in 2009 than in 1998, suggesting an increase in this ratio in time. This was possibly due to to enhanced levels of sea ice melt in 2009, 2010 and 2011. At least some of this additional sea ice melt was likely advected into the Fram Strait from the Beaufort Gyre and from the region north of the Bering Strait. Furthermore, changes in the advective pathways and in the production regions of brine from ice formation on the Siberian shelves may have influenced the ratio.

- Comparison with other analyses indicates that the variation in liquid freshwater component transports we observed between our surveys in the Fram Strait cannot be attributed to variability in the Arctic liquid freshwater inflow from rivers. However, known multi-year variability in the inflow of meteoric water and Pacific Water through the Bering Strait could have influenced the variations we observed.

- Recent observations of increasing liquid freshwater storage in the Arctic Ocean since the 1990s and model simulations suggest a decreased export of liquid freshwater. However, our results from the six surveys do not suggest a trend in Arctic liquid freshwater export through the upper Western Fram Strait. This is in accordance with previous studies using year-round mooring observations for part of the section. This raises the question how fast the accumulated liquid freshwater will be exported in the future, ultimately to the deep water formation regions of the North Atlantic, and if an increased export will occur through the Fram Strait. Future analyses of year-round mooring observations and further hydrographic sections will give more insight into any changes in liquid freshwater exports through the Fram Strait.

- Our results have to be seen in light of the fact that our surveys only cover six months within all $11 \mathrm{yr}$. Whereas we can estimate the error in the average transports with some confidence, it is difficult to assess how representative our surveys are for interannual or longer timescales. Currently, these surveys are the only way to study the variability in transports of meteoric water, net sea ice brine and Pacific Water from observations. Future studies of autonomous sampling systems may shed further light onto the variability of these water masses.

Acknowledgements. We thank all the scientists and crew of the different survey campaigns that contributed to this work. We thank both reviewers for their comments. This work was supported by the Co-Operative Project "The North Atlantic as Part of the Earth System: from System Comprehension to Analysis of Regional Impacts" funded by the German Federal Ministry for Education and Research (BMBF), project \# 03F0605E. Paul Dodd was funded by the Norwegian Research Council under the IPY project "IAOOS Norway: Closing the loop". This study contributes to UK Natural Environment Research Council project NER/T/S/2002/00453.

Edited by: A. Sterl 


\section{References}

Aaboe, S. and Nost, O. A.: A Diagnostic Model of the Nordic Seas and Arctic Ocean Circulation: Quantifying the Effects of a Variable Bottom Density along a Sloping Topography, J. Phys. Oceanogr., 38, 2685-2703, doi:10.1175/2008JPO3862.1, 2008.

Aaboe, S., Nost, O. A., and Hansen, E.: Along-slope variability of barotropic transport in the Nordic Seas: Simplified dynamics tested against observations, J. Geophys. Res., 114, C03009, doi:10.1029/2008JC005094, 2009.

Aagaard, K. and Coachman, L.: The East Greenland Current North of Denmark Strait: Part II, ARCTIC, 21, http://arctic. synergiesprairies.ca/arctic/index.php/arctic/article/view/3270 (last access: 28 January 2013), 1968.

Abrahamsen, E. P., Meredith, M. P., Falkner, K. K., Torres-Valdes, S., Leng, M. J., Alkire, M. B., Bacon, S., Laxon, S. W., Polyakov, I., and Ivanov, V.: Tracer-derived freshwater composition of the Siberian continental shelf and slope following the extreme Arctic summer of 2007, Geophys. Res. Lett., 36, L07602, doi:10.1029/2009GL037341, 2009.

Alkire, M. B., Falkner, K. K., Rigor, I., Steele, M., and Morison, J.: The return of Pacific waters to the upper layers of the central Arctic Ocean, Deep-Sea Res. Pt. I, 54, 1509-1529, 2007.

Anderson, L. G., Jutterström, S., Kaltin, S., Jones, E. P., and Björk, G.: Variability in river runoff distribution in the Eurasian Basin of the Arctic Ocean, J. Geophys. Res.-Oceans, 109, C01016, doi:10.1029/2003JC002120, 2004.

Bauch, D., Schlosser, P., and Fairbanks, R. G.: Freshwater balance and the sources of deep and bottom waters in the Arctic Ocean inferred from the distribution of $\mathrm{H}_{2}{ }^{18} \mathrm{O}$, Prog. Oceanogr., 35, 5380, 1995.

Bauch, D., Erlenkeuser, H., and Andersen, N.: Water mass processes on Arctic shelves as revealed from $\delta^{18} \mathrm{O}$ of $\mathrm{H}_{2} \mathrm{O}$, Global Planet. Change, 48, 165-174, 2005.

Bauch, D., Dmitrenko, I. A., Wegner, C., Hoelemann, J., Kirillov, S. A., Timokhov, L. A., and Kassens, H.: Exchange of Laptev Sea and Arctic Ocean halocline waters in response to atmospheric forcing, J. Geophys. Res.-Oceans, 114, C05008, doi:10.1029/2008JC005062, 2009.

Bauch, D., Gröger, M., Dmitrenko, I., Hölemann, J., Kirillov, S., Mackensen, A., Taldenkova, E., and Andersen, N.: Atmospheric controlled freshwater release at the Laptev Sea continental margin, Polar Res., 30, 5858 doi:10.3402/polar.v30i0.5858, $2011 \mathrm{a}$.

Bauch, D., van der Loeff, M. R., Andersen, N., TorresValdes, S., Bakker, K., and Abrahamsen, E. P.: Origin of freshwater and polynya water in the Arctic Ocean halocline in summer 2007, Prog. Oceanogr., 91, 482-495, doi:10.1016/j.pocean.2011.07.017, 2011b.

Behrendt, A.: Comparison of the Current Field in Fram Strait derived from ADCP Measurements and Mooring Data, Master's thesis, University of Bremen, 2008.

Beszczynska-Möller, A. and Wisotzki, A.: Physical oceanography during POLARSTERN cruise ARK-XXIII/2, Alfred Wegener Institute for Polar and Marine Research, Bremerhaven, doi:10.1594/PANGAEA.733424, 2010.

Beszczynska-Möller, A., Fahrbach, E., Schauer, U., and Hansen, E.: Variability in Atlantic water temperature and transport at the entrance to the Arctic Ocean, 1997-2010, ICES J. Mar. Sci., 69, 852-863, doi:10.1093/icesjms/fss056, 2012.
Cox, K. A., Stanford, J. D., McVicar, A. J., Rohling, E. J., Heywood, K. J., Bacon, S., Bolshaw, M., Dodd, P. A., De la Rosa, S., and Wilkinson, D.: Interannual variability of Arctic sea ice export into the East Greenland Current, J. Geophys. Res., 115, C12063, doi:10.1029/2010JC006227, 2010.

de Steur, L., Hansen, E., Gerdes, R., Karcher, M., Fahrbach, E., and Holfort, J.: Freshwater fluxes in the East Greenland Current: A decade of observations, Geophys. Res. Lett., 36, L23611, doi:10.1029/2009GL041278, 2009.

Dickson, R., Rudels, B., Dye, S., Karcher, M., Meincke, J., and Yashayaev, I.: Current estimates of freshwater flux through Arctic and subarctic seas, Prog. Oceanogr., 73, 210-230, doi:10.1016/j.pocean.2006.12.003, 2007.

Dodd, P. A., Heywood, K. J., Meredith, M. P., Naveira-Garabato, A. C., Marca, A. D., and Falkner, K. K.: Sources and fate of freshwater exported in the East Greenland Current, Geophys. Res. Lett., 36, L19608, doi:10.1029/2009GL039663, 2009.

Dodd, P. A., Rabe, B., Hansen, E., Falck, E., Mackensen, A., Rohling, E., Stedmon, C., and Kristiansen, S.: The freshwater composition of the Fram Strait outflow derived from a decade of tracer measurements, J. Geophys. Res., 117, C11005, doi:10.1029/2012JC008011, 2012.

Dukhovskoy, D., Johnson, M., and Proshutinsky, A.: Arctic decadal variability from an idealized atmosphere-ice-ocean model: 2 . Simulation of decadal oscillations, J. Geophys. Res., 111, C06029, doi:10.1029/2004JC002820, 2006.

Ekwurzel, B., Schlosser, P., Mortlock, R. A., and Fairbanks, R. G.: River runoff, sea ice meltwater, and Pacific water distribution and mean residence times in the Arctic Ocean, J. Geophys. Res., 106, 9075-9092, 2001.

Fahrbach, E.: Shipboard acoustic doppler current profiling during cruise ARK-XIV/2a, SAC ID 00493, doi:10.1594/PANGAEA.318314, http://store.pangaea.de/ Projects/WOCE/SADCP/PS52_00493.pdf, 2005.

Fahrbach, E. and VEINS members: Hydrochemistry measured on water bottle samples during POLARSTERN cruise ARK-XIV/2, Alfred Wegener Institute for Polar and Marine Research, Bremerhaven, doi:10.1594/PANGAEA.759130, 2010.

Fahrbach, E., Meincke, J., Østerhus, S., Rohardt, G., Schauer, U., Tverberg, V., and Verduin, J.: Direct measurements of volume transports through Fram Strait, Polar Res., 20, 217-224, 2001.

Fahrbach, E., Rohardt, G., and Sieger, R., eds.: 25 Years of Polarstern Hydrography (1982-2007), 5, Alfred Wegener Institute for Polar and Marine Research: Bremerhaven, 88 pp., 10.2312/wdc-mare.2007.5, 2007.

Falck, E., Kattner, G., and Budeus, G.: Disappearance of Pacific Water in the northwestern Fram Strait, Geophys. Res. Lett., 32, L14619, doi:10.1029/2005GL023400, 2005.

Foldvik, A., Aagaard, K., and Törresen, T.: On the velocity field of the East Greenland Current, Deep-Sea Res., 35, 1335-1354, 1988.

Häkkinen, S.: A simulation of the thermohaline effects of a great salinity anomaly, J. Climate, 12, 1781-1795, 1999.

Häkkinen, S. and Proshutinsky, A.: Freshwater content variability in the Arctic Ocean, J. Geophys. Res., 109, C03051, doi:10.1029/2003JC001940, 2004.

Holfort, J., Hansen, E., Østerhus, S., Dye, S., Jonsson, S., Meincke, J., Mortensen, J., and Meredith, M.: Freshwater fluxes east of Greenland, in: Arctic-Subarctic Ocean Fluxes: Defining the role 
of the Northern Seas in climate, edited by: Dickson, R. R., Meincke, J., and Rhines, P., chapter 11, 263-287, Springer Science and Business Media, 2008.

Jahn, A., Tremblay, L. B., Newton, R., Holland, M. M., Mysak, L. A., and Dmitrenko, I. A.: A tracer study of the Arctic Ocean's liquid freshwater export variability, J. Geophys. Res., 115, C07015, doi:10.1029/2009JC005873, 2010.

Jahn, A., Aksenov, Y., de Cuevas, B., de Steur, L., Hakkinen, S., Hansen, E., Herbaut, C., Houssais, M.-N., Karcher, M. J., Kauker, F., Lique, C., Nguyen, A. T., Pemberton, P., Worthen, D. L., and Zhang, J.: Arctic Ocean freshwater - How robust are model simulations?, J. Geophys. Res., 117, C00D16, doi:10.1029/2012JC007907, 2012.

Jakobsson, M., Macnab, R., Mayer, L., Anderson, R., Edwards, M., Hatzky, J., Schenke, H. W., and Johnson, P.: An improved bathymetric portrayal of the Arctic Ocean: Implications for ocean modeling and geological, geophysical and oceanographic analyses, Geophys. Res. Lett., 35, L07602, doi:10.1029/2008GL033520, 2008.

Jones, E. P., Anderson, L. G., and Swift, J. H.: Distribution of Atlantic and Pacific waters in the upper Arctic Ocean: Implications for circulation, Geophys. Res. Lett., 25, 765-768, 1998.

Jones, E. P., Anderson, L. G., Jutterström, S., Mintrop, L., and Swift, J. H.: Pacific fresh water, river water and sea ice meltwater across Arctic Ocean basins: Results from the 2005 Beringia Expedition, J. Geophys. Res., 113, C08012, doi:10.1029/2007JC004124, 2008a.

Jones, E. P., Anderson, L. G., Jutterström, S., and Swift, J. H.: Sources and distribution of freshwater in the East Greenland Current, Prog. Oceanogr., 78, 37-44, doi:10.1016/j.pocean.2007.06.003, 2008b.

Jónsson, S., Foldvik, A., and Aagaard, K.: The structure and atmospheric forcing of the mesoscale velocity field in Fram Strait, J. Geophys. Res., 97, 12 585-12 600, 1992.

Karcher, M., Gerdes, R., Kauker, F., Köberle, C., and Yashayaev, I.: Arctic Ocean change heralds North Atlantic freshening, Geophys. Res. Lett., 32, L21606, doi:10.1029/2005GL023861, 2005.

Karcher, M., Gerdes, R., and Kauker, F.: Modeling of $\delta^{18} \mathrm{O}$ and ${ }^{99} \mathrm{Tc}$ dispersion in Arctic and subarctic seas, available from: http: //asof.npolar.no, 2006.

Korhonen, M., Rudels, B., Marnela, M., Wisotzki, A., and Zhao, J.: Time and space variability of freshwater content, heat content and seasonal ice melt in the Arctic Ocean from 1991 to 2011, Ocean Sci. Discuss., 9, 2621-2677, doi:10.5194/osd-92621-2012, 2012.

Lansard, B., Mucci, A., Miller, L. A., Macdonald, R. W., and Gratton, Y.: Seasonal variability of water mass distribution in the southeastern Beaufort Sea determined by total alkalinity and delta O-18, J. Geophys. Res., 117, C03003, doi:10.1029/2011JC007299, 2012.

Latarius, K. and Quadfasel, D.: Seasonal to inter-annual variability of temperature and salinity in the Greenland Sea Gyre: heat and freshwater budgets, Tellus A, 62, 497-515, doi:10.1111/j.16000870.2010.00453.x, 2010.

Lique, C., Treguier, A. M., Scheinert, M., and Penduff, T.: A model-based study of ice and freshwater transport variability along both sides of Greenland, Clim. Dynam., 33, 685-705, doi:10.1007/s00382-008-0510-7, 2009.
Losch, M., Sidorenko, D., and Beszczynska-Möller, A.: FEMSECT: An inverse section model based on the finite element method, J. Geophys. Res., 110, C12023, doi:10.1029/2005JC002910, 2005.

Macdonald, R., Paton, D., Carmack, E., and Omstedt, A.: The freshwater budget and under-ice spreading of Mackenzie river water in the Canadian Beaufort Sea based on salinity and O-18/O-16 measurements in water and ice, J. Geophys. Res.-Oceans, 100, 895-919, doi:10.1029/94JC02700, 1995.

Manabe, S. and Stouffer, R. J.: The role of thermohaline circulation in climate, Tellus A, 51, 91-109, 1999.

Mauritzen, C.: Oceanography Arctic freshwater, Nat. Geosci., 5, 162-164, doi:10.1038/ngeo1409, 2012.

Melling, H. and Moore, R. M.: Modification of halocline source waters during freezing on the Beaufort Sea shelf: evidence from oxygen isotopes and dissolved nutrients, Cont. Shelf. Res., 15, 89-113, 1995.

Meredith, M., Heywood, K., Dennis, P., Goldson, L., White, R., Fahrbach, E., Schauer, U., and Østerhus, S.: Freshwater fluxes through the western Fram Strait, Geophys. Res. Lett., 28, 16151618, 2001.

Nansen, F.: The First Crossing of Greenland, Longmans, Green, translated by: Hubert M. Gepp., 1890.

Nguyen, A. T., Menemenlis, D., and Kwok, R.: Arctic iceocean simulation with optimized model parameters: Approach and assessment, J. Geophys. Res., 116, C04025, doi:10.1029/2010JC006573, 2011.

Østlund, H. G. and Hut, G.: Arctic Ocean water mass balance from isotope data, J. Geophys. Res., 89, 6373-6381, 1984.

Overeem, I. and Syvitski, J. P. M.: Shifting discharge peaks in Arctic rivers, 1977-2007, Geogr. Ann., 92A, 285-296, 2010.

Padman, L. and Erofeeva, S.: A barotropic inverse tidal model for the Arctic Ocean, Geophys. Res. Lett., 31, L02303, doi:10.1029/2003GL019003, 2004.

Proshutinksy, A. Y. and Johnson, M. A.: Two circulation regimes of the wind-driven Arctic Ocean, J. Geophys. Res., 102, 1249312514, 1997.

Proshutinsky, A., Krishfield, R., Timmermans, M.-L., Toole, J., Carmack, E., McLaughlin, F., Williams, W. J., Zimmermann, S., Itoh, M., and Shimada, K.: Beaufort Gyre freshwater reservoir: State and variability from observations, J. Geophys. Res.Oceans, 114, C00A10, doi:10.1029/2008JC005104, 2009.

Rabe, B., Schauer, U., Mackensen, A., Karcher, M., Hansen, E., and Beszczynska-Möller, A.: Freshwater components and transports in the Fram Strait - recent observations and changes since the late 1990s, Ocean Sci., 5, 219-233, doi:10.5194/os-5-219-2009, 2009.

Rabe, B., Muenchow, A., Johnson, H. L., and Melling, H.: Nares Strait hydrography and salinity field from a 3-year moored array, J. Geophys. Res., 115, C07010, doi:10.1029/2009JC005966, 2010.

Rabe, B., Karcher, M., Schauer, U., Toole, J., Krishfield, R., Pisarev, S., Kauker, F., Gerdes, R., and Kikuchi, T.: An assessment of Arctic Ocean freshwater content changes from the 1990s to 2006-2008, Deep-Sea Res. Pt. I, 58, 173-185, doi:10.1016/j.dsr.2010.12.002, 2011.

Rabe, B., Beszczynska-Möller, A., Fahrbach, E., Rohardt, G., and Schauer, U.: Physical oceanography and current meter data from various moorings from the North Greenland Sea, list of links to datasets, doi:10.1594/PANGAEA.803552, 2012. 
Rennermalm, A. K., Wood, E. F., Weaver, A. J., Eby, M., and Derý, S. J.: Relative sensitivity of the Atlantic meridional overturning circulation to river discharge into Hudson Bay and the Arctic Ocean, J. Geophys. Res., 112, G04S45, doi:10.1029/2006JG000330, 2007.

Rudels, B.: Constraints on exchanges in the Arctic Mediterraneando they exist and can they be of use?, Tellus A, 62A, 109-122, doi:10.1111/j.1600-0870.2009.00425.x, 2010.

Rudels, B., Björk, G., Nilsson, J., Winsor, P., Lake, I., and Nohr, C.: The interaction between waters from the Arctic Ocean and the Nordic Seas north of Fram Strait and along the East Greenland Current: results from the Arctic Ocean-02 Oden expedition, J. Mar. Syst., 55, 1-30, doi:10.1016/j.jmarsys.2004.06.008, 2005.

Schauer, U. and Beszczynska-Möller, A.: Problems with estimation and interpretation of oceanic heat transport - conceptual remarks for the case of Fram Strait in the Arctic Ocean, Ocean Sci., 5, 487-494, doi:10.5194/os-5-487-2009, 2009.

Schauer, U. and Budéus, G.: Physical oceanography during POLARSTERN cruise ARK-XIV/2, Alfred Wegener Institute for Polar and Marine Research, Bremerhaven, doi:10.1594/PANGAEA.733424, 2010.

Schauer, U. and Rohardt, G.: Physical oceanography during POLARSTERN cruise ARK-XXI/1b, Alfred Wegener Institute for Polar and Marine Research, Bremerhaven, doi:10.1594/PANGAEA.742621, 2010.

Schauer, U. and Wisotzki, A.: Physical oceanography during POLARSTERN cruise ARK-XX/2, Alfred Wegener Institute for Polar and Marine Research, Bremerhaven, doi:10.1594/PANGAEA.742660, 2010.

Schauer, U., Fahrbach, E., Osterhus, S., and Rohardt, G.: Arctic warming through the Fram Strait: Oceanic heat transport from 3 years of measurements, J. Geophys. Res.-Oceans, 109, C06026, doi:10.1029/2003JC001823, 2004.

Schlichtholz, P.: Climatological baroclinic forcing of the barotropic flow in the East Greenland Current in Fram Strait, J. Geophys. Res., 110, C08013, doi:10.1029/2004JC002701, 2005.

Schlichtholz, P. and Houssais, M.-N.: An overwiew of the $\theta-$ S correlations in Fram Strait based on the MIZEX 84 data, Oceanologia, 44, 243-272, 2001.

Serreze, M. C., Barrett, A. P., Slater, A. G., Woodgate, R. A., Aagaard, K., Lammers, R. B., Steele, M., Moritz, R., Meredith, M., and Lee, C. M.: The large-scale freshwater cycle of the Arctic, J. Geophys. Res.-Oceans, 111, C11010, doi:10.1029/2005JC003424, 2006.

Steele, M. and Boyd, T.: Retreat of the cold halocline layer in the Arctic Ocean, J. Geophys. Res., 103, 10419-10439, 1998.

Sutherland, D. A., Pickart, R. S., Jones, E. P., Azetsu-Scott, K., Eert, A. J., and Olafsson, J.: Freshwater composition of the waters off southeast Greenland and their link to the Arctic Ocean, J. Geophys. Res., 114, C05020, doi:10.1029/2008JC004808, 2009.

Talley, L. D.: Freshwater transport estimates and the global overturning circulation: Shallow, deep and throughflow components, Prog. Oceanogr., 78, 257-303, doi:10.1016/j.pocean.2008.05.001, 2008.
Taylor, J., Falkner, K., Schauer, U., and Meredith, M.: Quantitative considerations of dissolved barium as a tracer in the Arctic Ocean, J. Geophys. Res.-Oceans, 108, 3374, doi:10.1029/2002JC001635, 2003.

Thompson, D. W. J. and Wallace, J. M.: The arctic oscillation signature in the wintertime geopotential height and temperature fields, Geophys. Res. Lett., 25, 1297-1300, 1998.

Timmermans, M.-L., Proshutinsky, A., Krishfield, R. A., Perovich, D. K., Richter-Menge, J. A., Stanton, T. P., and Toole, J. M.: Surface freshening in the Arctic Oceans Eurasian Basin: an apparent consequence of recent change in the winddriven circulation, J. Geophys. Res., 116, C00D03, doi:10.1029/2011JC006975, 2011.

Toole, J. M., Timmermans, M. L., Perovich, D. K., Krishfield, R. A., Proshutinsky, A., and Richter-Menge, J. A.: Influences of the ocean surface mixed layer and thermohaline stratification on Arctic Sea ice in the central Canada Basin, J. Geophys. Res., 115, C10018, doi:10.1029/2009JC005660, 2010.

Visbeck, M.: Deep velocity profiling using lowered acoustic Doppler current profilers: Bottom track and inverse solutions, J. Atmos. Ocean. Tech., 19, 794-807, doi:10.1175/15200426(2002)019;0794:DVPULA ;2.0.CO;2, 2002.

Woodgate, R. A., Aagaard, K., and Weingartner, T. J.: Interannual changes in the Bering Strait fluxes of volume, heat and freshwater between 1991 and 2004, Geophys. Res. Lett., 33, L15609, doi:10.1029/2006GL026931, 2006.

Woodgate, R. A., Weingartner, T. J., and Lindsay, R.: Observed increases in Bering Strait oceanic fluxes from the Pacific to the Arctic from 2001 to 2011 and their impacts on the Arctic Ocean water column, Geophys. Res. Lett., 39, L24603, doi:10.1029/2012GL054092, 2012.

Yamamoto-Kawai, M., Tanaka, N., and Pivovarov, S.: Freshwater and brine behaviors in the Arctic Ocean deduced from historical data of delta O-18 and alkalinity (1929-2002 AD), J. Geophys. Res., 110, C10003, doi:10.1029/2004JC002793, 2005.

Yamamoto-Kawai, M., Carmack, E., and McLaughlin, F.: Nitrogen balance and Arctic throughflow, Nature, 443, 7107, doi:10.1038/443043a, 2006.

Yamamoto-Kawai, M., McLaughlin, F. A., Carmack, E. C., Nishino, S., and Shimada, K.: Freshwater budget of the Canada Basin, Arctic Ocean, from salinity, $\delta^{18} \mathrm{O}$, and nutrients, J. Geophys. Res., 113, C01007, doi:10.1029/2006JC003858, 2008.

Yamamoto-Kawai, M., McLaughlin, F. A., Carmack, E. C., Nishino, S., Shimada, K., and Kurita, N.: Surface freshening of the Canada Basin, 2003-2007: River runoff versus sea ice meltwater, J. Geophys. Res., 114, C00A05, doi:10.1029/2008JC005000, 2009.

Zhang, D., McPhaden, M. J., and Johns, W. E.: Observational evidence for flow between the subtropical and tropical Atlantic: The Atlantic tropical cells, J. Phys. Oceanogr., 33, 1783-1797, 2003.

Zhang, X., Sorteberg, A., Zhang, J., Gerdes, R., and Comiso, J. C.: Recent radical shifts of atmospheric circulations and rapid changes in Arctic climate system, Geophys. Res. Lett., 35, L22701, doi:10.1029/2008GL035607, 2008. 